IZA DP No. 5835

Wage Rigidity, Collective Bargaining and the Minimum Wage:

Evidence from French Agreement Data

Sanvi Avouyi-Dovi

Denis Fougère

Erwan Gautier

July 2011 


\title{
Wage Rigidity, Collective Bargaining and the Minimum Wage: Evidence from French Agreement Data
}

\author{
Sanvi Avouyi-Dovi \\ Banque de France \\ and Leda-SDFi, Université de Paris-Dauphine \\ Denis Fougère \\ CREST, CNRS, CEPR, \\ Banque de France and IZA \\ Erwan Gautier \\ Université de Nantes, IEMN-IAE, LEMNA \\ and Banque de France
}

Discussion Paper No. 5835

July 2011

IZA

P.O. Box 7240

53072 Bonn

Germany

Phone: +49-228-3894-0

Fax: +49-228-3894-180

E-mail: iza@iza.org

\begin{abstract}
Any opinions expressed here are those of the author(s) and not those of IZA. Research published in this series may include views on policy, but the institute itself takes no institutional policy positions.

The Institute for the Study of Labor (IZA) in Bonn is a local and virtual international research center and a place of communication between science, politics and business. IZA is an independent nonprofit organization supported by Deutsche Post Foundation. The center is associated with the University of Bonn and offers a stimulating research environment through its international network, workshops and conferences, data service, project support, research visits and doctoral program. IZA engages in (i) original and internationally competitive research in all fields of labor economics, (ii) development of policy concepts, and (iii) dissemination of research results and concepts to the interested public.
\end{abstract}

IZA Discussion Papers often represent preliminary work and are circulated to encourage discussion. Citation of such a paper should account for its provisional character. A revised version may be available directly from the author. 


\title{
ABSTRACT
}

\section{Wage Rigidity, Collective Bargaining and the Minimum Wage: Evidence from French Agreement Data}

\begin{abstract}
Using several unique data sets on wage agreements at both industry and firm levels in France, we document stylized facts on wage stickiness and the impact of wage-setting institutions on wage rigidity. First, the average duration of wages is a little less than one year and around 10 percent of wages are modified each month by a wage agreement. Data patterns are consistent with predictions of a mixture of Calvo and Taylor models. The frequency of wage change agreements is rather staggered over the year but the frequency of effective wage changes is seasonal. The national minimum wage has a significant impact on the probability of a wage agreement and on the seasonality of wage changes. Negotiated wage increases are correlated with inflation, the national minimum wage increases and the firm profitability.
\end{abstract}

JEL Classification: J31, J50, E30

Keywords: $\quad$ wage stickiness, wage bargaining, minimum wage, downward nominal wage rigidity

Corresponding author:

Denis Fougère

CREST-INSEE

15 Boulevard Gabriel Péri

92245 Malakoff Cedex

France

E-mail: fougere@ensae.fr

\footnotetext{
* We thank Laurent Baudry for his valuable research assistance. We thank the editor and two anonymous referees whose comments and suggestions helped us to significantly improve our manuscript. We also thank for their remarks Olivier Barrat, Pierre Cahuc, Gilbert Cette, Louis Christofides, Hervé Le Bihan, François Langot, Antoine Naboulet, Sara de la Rica, Christian Toft, and participants in the "Wage Bargaining, Employment, and Monetary and Economic Policies" Conference (Paris, October 2007), the 25th Journées de Microéconomie Appliquée (Saint-Denis de la Réunion, May 2008), the 58th AFSE Congress (Nanterre, September 2009), the 16th International Conference on Panel Data (Amsterdam, July 2010), the Royal Economic Society Conference (London, April 2011), and seminars at Banque de France (Paris, May 2010), French Ministry of Labour (Paris, June 2010), University of Nantes (September 2010), CREST (October 2010), University of Cyprus (May 2011) and University of Le Mans (May 2011). Finally, we are also grateful to Sébastien Roux for facilitating our access to Déclarations Annuelles de Données Sociales (DADS) data through the Centre d'Accès Sécurisé Distant (CASD, INSEE, Paris). The views expressed in this paper do not necessarily reflect those of the Banque de France.
} 


\section{Introduction}

In most macroeconomic models, the existence of nominal rigidities explains why monetary policy might have real impact on output. Until recently, the micro empirical research on nominal rigidities mainly focused on price stickiness (Klenow and Malin, 2011) and evidence on nominal wage rigidity is rather scarce. ${ }^{1}$ However, Huang and Liu (2002) and Christiano et al. (2005) have emphasized that wage rigidity might be much more important than price rigidity to replicate the dynamic impact of monetary policy on output. ${ }^{2}$ In this paper, we document stylized facts on wage stickiness and the impact of wage-setting institutions on wage rigidity in France using administrative data set on collective wage agreements at industry and firm levels between 1994 and 2005.

Our first contribution is to provide new stylized facts on wage stickiness and to confront them with predictions of wage rigidity models. We find that the monthly frequency of wage changes implied by wage agreements is a little less than 10 percent and the average duration of negotiated wages is 10 months. In the United States, wages are a little stickier; using wage contract or observed wage data, Taylor (1999) and Barattieri et al. (2009) show that the average duration of wages is about one year. In France, contrary to price rigidity, heterogeneity across industries is limited but longer wage durations are found in small firms. Hazard rates of wage change agreements exhibit large peaks at 12 and 24 months whereas hazard rates of effective wage changes exhibit peaks at 3, 6, 12 and 24 months. This pattern is consistent with the existence of fixed duration contracts $\grave{a}$ la Taylor (1980). For other durations, hazard rates are rather flat. This would suggest the existence of a significant proportion of Calvo wage-setting firms in our data. Consistent with the model set forth by Fischer (1977), we find that many wage increases are predetermined: 44 percent of firm-level agreements and about 20 percent of industry-level agreements stipulate more than one wage increase. However, a majority of agreements covers only one year. We also find that inflation and national minimum wage increases are correlated with negotiated wage increases. This fact may support the presence of an implicit indexation mechanism in wage agreements. Moreover, firm profitability has a significant positive impact on the size of wage increases whereas local unemployment has a negative effect on negotiated wage increases at the firm level.

Some papers have recently assessed the seasonal effects of monetary shocks. Olivei and Tenreyro (2010) find that an uneven staggering of wage contracts across quarters in Europe can explain the delayed and persistent effects of monetary policy shocks on output. However, evidence on wage change seasonality is rather scarce. Here we examine evidence on the synchronization of wage agreements and effective wage changes. Wage agreements are synchronized at each level of the wage bargaining process but staggered across the different levels of this process. More than half of industrylevel agreements are signed between October and January whereas about 60 percent of firm-level agreements occur between December and April. Overall, wage change decisions are rather staggered: the frequency of wage changes is 25 percent in the first and the second quarters versus 28 and 35 percent in the third and the fourth quarters, respectively. Dates of effect of wage agreements are more seasonal: a first peak in the frequency of wage changes is observed in January (36.2 percent) and a second one in July (26.9 percent).

Finally, our paper provides new evidence on the role of wage-setting institutions on wage rigidity. The French system of wage bargaining is quite representative of European institutional features of wage bargaining: almost all workers are covered by a wage agreement, different levels of wage bargaining coexist, and a significant proportion of workers are paid the minimum wage. Aghion et al.

\footnotetext{
${ }^{1}$ Recent exceptions include Heckel et al. (2008) for France, and Barattieri et al. (2009) for the United States.

${ }^{2}$ On the introduction of wage rigidity in DSGE models, see Erceg et al. (2000) and Gali (2011) for a recent survey.
} 
(2011) have pointed out the role of public institutions on the quality of labor relations: a binding national minimum wage might crowd out the possibility for agents to negotiate. We find that the higher the percentage of minimum-wage workers, the less frequently firms negotiate. ${ }^{3}$ Industry-level agreements are more likely to cover small firms and to be binding for low-paid workers whereas firmlevel agreements concern larger firms and higher paid workers. Systematic links between industryand firm-level agreements are difficult to observe. However the national minimum wage plays a key role in the wage bargaining calendar and it modifies the patterns of wage changes over the year.

Our paper is organized as follows. Section 2 presents the main institutional features of the wage setting process in France and describes our data sets and how we measure wage rigidity. Section 3 documents evidence on the frequency of wage changes and wage durations. Section 4 provides results on the timing of wage agreements. Finally, the distribution of wage changes in collective agreements and its determinants are examined in Section 5. Section 6 concludes.

\section{Wage-bargaining institutions and data}

\subsection{Institutions of wage bargaining}

Four institutional principles govern collective bargaining in France.

First, a law (the Auroux Law, voted in 1982) stipulates that each year, every firm and every industry must negotiate wages with unions even if an agreement cannot be reached at the end of the bargaining process.

Secondly, there is a strict hierarchy between the different levels of wage bargaining. In France, wages are bargained at three different levels: $(i)$ at the national level, a binding minimum wage is set by the government according to an official formula (see below); (ii) at the industry level, employers' organisations and unions negotiate pay scales and wages are negotiated occupation by occupation; (iii) at the firm level, employers and unions usually negotiate wage increases. The hierarchy between bargaining levels implies that a collective agreement must set forth, broaden or enhance an agreement which has been previously signed at a higher bargaining level. At the industry level, if the wage bargaining fails, the previous pay scale prevails until a new agreement is signed. At the firm level, if there is no collective agreement on wages in a given year, there is no collective wage increase but individual wage increases are possible. On average, around 66 percent of workers are covered by an industry-level wage agreement each year. Firm-level wage agreements cover a smaller proportion of workers (about 20 percent; see Appendix, Table A).

The third principle is the wide use of extension procedures which guarantee a large coverage of collective agreements. In France, there is a gap between the low unionization rate (less than 10 percent) and the large coverage of wage agreements. ${ }^{4}$ This gap may have two different causes: $(i)$ a firm-level agreement usually covers all workers within the firm and not only unionized workers (like in the United States or in the United Kingdom); (ii) at the industry level, extension procedures permit agreements to apply to all workers within an industry. At first, an industry-level wage agreement applies to all firms represented by the employers' associations signing the text. Then, an extension of the agreement to the whole industry can be requested either by the government, by employers' associations or by unions. Once extended, the agreement applies to all workers within the industry. Extension procedures are common in France and no specific criterion is needed to obtain an extension.

\footnotetext{
${ }^{3}$ On the effect of the minimum wage on prices, see for instance Fougère et al. (2010).

${ }^{4}$ In countries like the United States or the United Kingdom, unionization is equal to the coverage of wage agreements.
} 
Lastly, the national minimum wage (NMW hereafter) ${ }^{5}$ is set at the national level and applies to all workers and to all firms. Minimum wage increases are binding. Until 2010, the NMW was raised every year in July ${ }^{6}$ according to a legal formula based on indexation to past inflation and to past wage growth. In addition to these indexation procedures, the government may decide, on a discretionary basis, to increase the raise. Over our sample period, the average NMW increases were higher than the average overall wage growth. On average, 13 percent of workers were paid the NMW whereas in most countries where a NMW exists, less than 5 percent of workers are paid the NMW (Du Caju et al., 2009).

\subsection{Data}

We use three original data sets containing precise information both on the agreements signed at the different levels of the wage bargaining process and on the share of minimum wage earners at the local and industry levels. A fourth data set helps us to provide a full characterization of firms and to identify firms which are not covered by a firm-level agreement.

\section{- Industry-level agreements}

In France, at the aggregate level, the bargaining system is made up of about 700 "branches". These branches do not exactly or systematically match industries of the usual classification of economic sectors or products. ${ }^{7}$ Some of them cover a very limited number of workers while others cover thousands of workers. ${ }^{8}$ Moreover, in a given firm, some workers can be covered by one branche others by another one. However, we often observe that a majority of workers in a firm are covered by only one branche and that branches often cover a whole industry. So, in our study, we use the term industry for "branche".

We have collected data on industry-level agreements from annual reports published by the Ministry of Labor over the period 1994-2005 (Rapports annuels sur la négociation). These reports list all wage agreements signed in a given year in industries with more than 10,000 workers. A little less than 2,000 wage agreements are reported, which corresponds to 206 industries. 123 industries have nationwide coverage, while 83 cover regional or local areas (this mainly concerns agreements in the metalworking and construction industries). All in all, the agreements contained in our data set cover around 12 million workers in 2005, which represents approximately 75 percent of workers employed in the private sector. The main variables include an identifying number for the industry, the geographical coverage of the agreement, the number of workers in the industry, the date of signature of the wage agreement (day/month/year) and the date at which it becomes effective (hereafter, this date is called the "date of effect"). For the period 1999-2005, the average wage increase contained in the agreement is also available. For a majority of industries, pay scales deal with monthly or annual base wages. One of the limitations of this data set is that the whole pay scales are not available. These scales are different across industries, and their comparison is thus difficult to undertake.

\section{- Firm-level agreements}

We also use an administrative data set containing information on all firm-level agreements collected by the Ministry of Labor. By law, firms must report to the Ministry of Labor all agreements they conclude. About 350,000 agreements (covering different topics) were collected over the period 1994-2005. The main variables include the scope of the agreement (wages, bonuses, workweek

\footnotetext{
${ }^{5}$ In France, the NMW is called Salaire Minimum Interprofessionnel de Croissance.

${ }^{6}$ Except in 1996 when the NMW was also increased in May.

${ }^{7}$ For instance, due to historical reasons, collective agreements in the metalworking industry signed at the local level may cover workers who are not actually working in metalworking industries.

${ }^{8}$ For example, collective agreements in the leather industry cover around 3,000 workers whereas collective agreements in the bakery industry cover approximately 115,000 workers.
} 
reduction, employment, discrimination, etc.) and the date of signature of the agreement (month/year). We restrict our sample to agreements dealing with wages. The date of effect and the wage increase reported in the agreement are also available but only for the period 1994-2001. ${ }^{9}$ In most firm-level wage agreements, collective wage increases refer to monthly base wage increases.

To match this data set with the industry-level wage agreements, we assume that all workers of a given firm are covered by only one industry wage agreement. We also assume that, if a firm-level agreement is signed in a given firm, all workers of this firm are covered by the agreement.

- National Minimum Wage

On average, over the sample period, 13 percent of workers are paid the NMW. To measure the role of the NMW in the bargaining process, we build a data set containing the proportion of workers paid around the NMW simultaneously in a given industry and a given département. ${ }^{10}$ For that purpose, we use exhaustive administrative files on wages (Déclarations Annuelles des Données Sociales, $D A D S$ ) which contain base wages and number of days paid each year to every worker. These data sets enable us to compute the proportion of days paid around the minimum wage (between 0.9 and 1.2 the hourly minimum wage) in a disaggregate industry (classification NES 114) and in a given département each year over the period 1994-2005. We thus compute a variable describing the importance of the NMW in the wage distribution at a disaggregate level.

\section{- Firm data}

Finally, we use a data set containing firm-level information to identify firms which negotiate but also firms which never agree on wages over the sample period. These latter firms are by definition not reported in the agreement data set. The firm level data set, called Fichier Bancaire des Entreprises (Fiben hereafter), is produced by the Banque de France. It contains annual information on the balance sheet of hundreds of thousands of firms. Some industries - like financial activities, education, health and administration - are excluded from this data set. The main variables used in our study include the number of workers in the firm, its geographical localization and firm profitability. Following Guertzgen (2009), we measure firm profitability as quasi rents per capita:

$$
\pi_{i t}=\frac{Y_{i t}-\text { Mat. } \text { Costs }_{i t}-N_{i t} \bar{w}_{t}}{N_{i t}}
$$

where $Y_{i t}$ is annual sales of firm $i$ in year $t$, Mat. Costs $s_{i t}$ annual material costs for firm $i$ in year $t, N_{i t}$ the number of employees in year $t$ in firm $i$, and $\bar{w}_{t}$ the average labor cost per capita at the industry level. This average industry wage bill is introduced to tackle a possible endogeneity issue due to the presence of an accounting relationship between profit and wages. We use two digit industry producer price index to deflate all monetary values. When conducting the statistical analysis of wage changes and agreements, we compute the annual log variation of this performance indicator.

Our final sample comes from the matching of the four data sets presented above. It contains all the firms in the Fiben data set, excluding firms belonging to industries not reported in the data set containing industry-level agreements. Our sample contains around 1.5 million of individual observations (i.e. 230,000 firms). The distribution of firms according to their size or to their economic activities is similar to the one in the whole economy (see Appendix, Table B).

\subsection{Measuring wage rigidity}

In macroeconomic models with nominal rigidities, key parameters are the probability of observing a wage change and the length of periods in which wages remain fixed. Using wage contract data, our

\footnotetext{
${ }^{9}$ Because of important methodological changes in the collection of information concerning agreements.

${ }^{10}$ A département is an administrative zone. There are 96 départements in France. Each of them has approximately the same geographical size $\left(6,000 \mathrm{~km}^{2}\right.$, i.e. four times an American county and three times an English county), but different populations.
} 
aim here is to measure the frequency of wage changes and the distribution of wage durations. ${ }^{11}$ The wage rate of a given worker can be modified because of a firm-level agreement, an industry-level agreement and/or an increase in the NMW. Ideally, for each worker, we would like to measure the distribution of durations between two wage change decisions or two wage changes implied by wage agreements.

To measure the elapsed duration since wages were last agreed upon (even if an agreement implies no wage increase), we have constructed, for all workers in a given firm, a dummy variable equal to one when a firm-level wage agreement or an industry-level agreement is signed and concerns this firm. This variable is supposed to capture wage changes agreed for workers paid above the minimum wage. For workers paid close to the minimum wage, the variable is also equal to one when the minimum wage is increased (usually in July). In each firm, the proportion of employees whose wage is close to the minimum wage is supposed to be equal to the proportion of days paid the minimum wage simultaneously at both local and industry levels. Using the number of workers in each firm, we are then able to measure the number of workers whose wages are affected by a firm-level agreement, an industry level agreement or an increase in the NMW.

In France, there is usually no expiry date in wage agreements since firms must negotiate wages every year. So, in a given year, if no agreement is signed at the firm level or at the industry level, workers are not covered by any contract and there is no collective wage increase. ${ }^{12}$ Consequently, the duration of wages in a firm is computed as the difference between two successive agreements, whatever the type of agreement (either an industry- or a firm-level agreement or an increase in the NMW). We are then able to measure how many months a wage remains fixed and to provide some basic statistics on the distribution of wage durations. We also compute the frequency of wage changes as the ratio of the number of workers concerned by a wage agreement to the total number of workers.

In macroeconomic models with wage rigidity, one generally tries to estimate the speed at which agents incorporate specific or common shocks into their wages. One interesting property of our data is that we are able to distinguish between the dates at which wage changes are agreed and the dates at which wage changes are actually implemented. As noted by Cecchetti (1987), the observation of actual wage changes can be misleading when assessing the degree of wage rigidity. For instance, let us consider two firms in which actual wages are modified every month. In the first firm, wages are negotiated every month based on the current information on shocks whereas, in the second firm, all wage changes were decided one year ago based on the information available at that date. In the first case, wages are considered as flexible whereas, in the second case, shocks would be more persistent. In this paper, we compute the frequency of agreed wage changes and the frequency of actual wage changes. ${ }^{13}$ Since we observe dates of effect at the firm level only for the period 1994-2001, we restrict the computation of these two indicators over this sub-period. ${ }^{14}$

Using wage contract data allows us to have very accurate information on the date at which a wage change is decided and is implemented in each firm. Many studies on wage rigidity use survey data collected once a year and they cannot provide direct evidence on the average duration of wage contracts at a high frequency. Moreover, most of the papers dealing with wage rigidity have to correct

\footnotetext{
11 The frequency of wage changes and the duration of wages are related since the average duration is a function of the inverse of the frequency of wage changes.

12 For the same reason, it is difficult to compute and to analyze delays in renewal of labor contracts, as in Gu and Kuhn (1998) or Danziger and Neuman (2005).

${ }^{13}$ For the national minimum wage, we assume that the decision and the effective date are the same. Firms know that the minimum wage will be modified in July but they can only forecast the size of NMW increases.

${ }^{14}$ As a robustness exercise, we have computed the same variables assuming that over the period 2001-2005; firm-level agreements are implemented (i.e. are "effective") at the date of the agreement. Results remain very similar.
} 
for measurement error in reported wages. Our data are more immune to this type of measurement error.

\section{Frequency and duration of wage agreements}

In this section, using micro data, we provide some estimates of the key parameters used in macro models with wage rigidity. Then, we confront our empirical findings to the main predictions of these models. Three models are often used in macroeconomics: (i) Taylor (1980) assumes that wages are set for a constant period of time. His model is mainly motivated by the existence of wage contracts in the US manufacturing sector (Cecchetti, 1987, and Taylor, 1983, for the United States, and Christofides and Wilton, 1983, for Canada). Taylor (1999) finds that one year is a good approximation of the average length of a wage contract; (ii) Calvo (1983) assumes that duration of wages is random; the probability of a wage change being exogenous and constant over time. This model is widely used in macroeconomic models but it is not motivated by strong institutional reasons. However, Fougère et al. (2007) show that, for prices, a Calvo model is a rather good approximation for the distribution of observed price durations; (iii) In menu cost models, the probability of a wage change depends on the state of the economy and it can vary over time.

\subsection{Frequency and durations of wage change decisions}

Table 1 reports some descriptive statistics concerning the duration of wages, the frequency of wage changes (agreed and effective) and implied durations of wages (defined as the inverse of the frequency of wage changes). Each month, about 10 percent of wages are modified by a wage agreement (either a firm- or an industry-level agreement, or an increase in the NMW level). The average duration of wages is close to 10 months. For the United States, using a macroeconomic model, Christiano et al. (2005) estimate that the average wage duration is about 8 months whereas, using individual wage data, Baratierri et al. (2009) find a longer average duration (about one year and a half).

\section{[Table 1]}

Figure 1a displays the distribution of durations between two decisions of wage changes. First, we find that most of the wage durations are lower than one year and that only 10 percent of durations are longer than 18 months. Second, the distribution exhibits a peak at 12 months: about 13 percent of wage durations are equal to one year. These two findings reflect both the legal obligation in France to negotiate wages every year and the regularity of the bargaining calendar (see section 4). If we refer to wage rigidity models, the peak at one year is in line with the predictions of a Taylor (1980) model where firms set their wages for a given and constant period of time (i.e. 12 months). For durations different from 12 months, the distribution can be approximated by an exponential distribution, which suggests the existence of Calvo type wage-setting firms.

\section{[Figure 1]}

Figure $1 \mathrm{~b}$ plots the hazard rate of wage agreement durations, i.e. the instantaneous conditional probability of a wage agreement given that no agreement has been signed since the last wage change. A basic Calvo model would predict a constant hazard rate whereas a Taylor model would predict that the hazard rate is equal to one when the contract is renewed (this date being defined ex ante) and zero elsewhere. We find that the hazard rate shows a peak above 40 percent at 12 months and remains flat below 10 percent elsewhere. This is consistent with the predictions of a mixture of Calvo and Taylor models.

Contrary to prices, the hazard of wage changes is not decreasing. This non-decreasing pattern in the hazard function may suggest a small degree of heterogeneity in wage-setter behaviors (Fougère et 
al., 2007). Table 2 examines two possible sources of heterogeneity, namely industry effects and the firm size. First, differences across industries are rather small; the frequency of wage change decisions is slightly smaller in the manufacturing sector than in services (10.8 percent versus 8.8 percent). The degree of heterogeneity is larger when we consider the size of firms. For firms with less than 100 employees, the average wage duration is about 13 months whereas for firms with more than 500 workers, the average duration is close to 8 months. This firm-size effect can be linked to the frequent absence of unions in firms with less than 50 workers. In small firms, less than 20 percent of workers are represented by a union, compared with 80 percent in firms with more than 500 workers (Amossé and Pignoni, 2006). In smaller firms, negotiating wages is more costly; thus the frequency of wage changes is lower.

\section{[Table 2]}

\subsection{Frequency and durations of effective wage changes}

Firms or industries may decide to predetermine wage changes in a wage agreement. Wage agreements can come into force at several dates in the future and wage increases are staggered over time. At both industry and firm levels, there may be a delay between the date of signature and the date at which the agreement actually comes into force..$^{15}$ Fischer (1977) shows that predetermined wage changes play a role in explaining why monetary policy is non-neutral in the short run. Even if all firms decide to change their wages in every period, monetary policy would still have an impact on the product in the presence of wage predetermination.

In Table 3, we compute the proportion of agreements stipulating a given number of dates of effect. 20 percent of industry-wage agreements contain more than one date of effect. However, the delay between the signature and the implementation of the agreement is often short. If the agreement contains a second date of effect, the duration between the decision of wage change and the effective wage change is 6 months on average. For firm-level agreements, the proportion of agreements containing more than one date of effect is larger (about 45 percent). The durations between the date of a wage change decision and the date at which the agreement becomes effective is short for the first effect (close to 0) and durations are about 6 and 8 months for the second and the third effects, respectively. Overall, the length of time between the date of signature and the last date of effect rarely exceeds 12 months. For this reason, staggering usually occurs over the course of the year. So, predetermination at a given level of bargaining may have rather limited effects.

[Table 3]

We now compare the distribution of durations of effective wage changes with our findings on wage change agreements. First, the average monthly frequency of effective wage changes is similar to the average frequency of wage change decisions, close to 10 percent (Table 1). There is some heterogeneity in the frequency of effective wage changes across industries and across firm sizes but it is smaller than for wage agreements (Table 2).

Figure 2a plots the distribution of durations between two effective wage changes. The peak at 12 months is larger than for the distribution of wage change decisions (more than 20 percent of wage durations are exactly equal to one year). Moreover, two other peaks in the distribution are observed at 3 and 6 months: around 16 percent of wage durations are equal to 6 months and 12 percent are equal to 3 months. This pattern may have two different causes: $(i)$ a given agreement could contain several dates of effect, or a wage rate could be modified by different agreements at different levels, (ii)

\footnotetext{
${ }^{15}$ Using Canadian wage agreements, Christofides and Laporte (2002) analyse what they call "intra contract wage profile".
} 
implementations of wage agreements (whatever the level of wage bargaining) are gathered in some specific months (see section 4), which leads to peaks at some specific durations.

\section{[Figure 2]}

On Figure $2 b$, we plot the hazard rate of effective wage durations. This hazard rate exhibits large peaks at 12, 24 and 36 months and two smaller ones at 3 and 6 months. Elsewhere, the hazard rate is flat, close to 5 percent. The large peak at 12 months reflects the importance of one-year Taylor contracts whereas the peaks at 24 and 36 months are due to the failure of negotiations in a given year. Smaller peaks at 3 and 6 months may indicate some staggering between the different levels of wage bargaining. This distribution is consistent with a mixture of a Taylor model and a Calvo model, but the proportion of Taylor firms might be higher for effective wage changes than for wage change agreements.

\subsection{Some determinants of the probability of a wage change}

A state-dependent model assuming wage adjustment cost would predict that state-dependent variables could explain the probability of wage changes. Here we examine determinants of the probability that a wage agreement is signed, either at the industry level or at the firm level in a given year. Tables 4 and 5 report estimates of Probit models applied to industry-level agreements and Logit models applied to firm-level agreements. In both cases, the dependent variable is a dummy variable taking the value 1 if an agreement is signed (or becomes effective) in a given year $t, 0$ otherwise. Both models incorporate unobserved individual effects.

First, at the firm level, we find a significant effect of the firm size on the probability of a firmlevel agreement. Larger firms are more likely to sign a wage agreement than small firms. At the industry-level, this firm-size effect is reversed: the higher the proportion of small firms within the industry, the more likely an agreement. Small firms may find it difficult and costly to negotiate on wages every year. Thus they prefer a common agreement at the industry level which is less costly to obtain. Gray (1978) shows that the length of contracts is positively related to negotiation costs; this may explain the heterogeneity of wage change frequencies across firm sizes.

At the industry level, the proportion of days paid the NMW has a positive but not significant effect on the probability of an industry-level agreement in a given year. This finding may seem counterintuitive. In fact, some studies show that the existence of a minimum wage reduces the level of social dialogue between workers and employers (see, for instance, Aghion et al., 2011). The causality seems to be reversed in some industries where bargaining occurs frequently because the NMW overtakes the bottom of the wage scales. This catching-up phenomenon forces industries to renegotiate quickly but new agreements merely adjust the lower end of wage scales to the new value of the NMW. At the firm level, the impact of the number of minimum wage earners on the probability of a wage agreement is negative. When the proportion of minimum-wage workers is high in a given firm, wage agreements are less frequent since wage increases are set at the national level for many of its workers. This finding is consistent with the conclusions of Aghion et al. (2011). Annual NMW increases allow smaller firms for which cost of negotiation is large to have longer and less frequent firm agreements because their wages are partly determined by the NMW changes. This finding is consistent with Gray (1978) who shows that contract length is positively correlated with the cost of contracting and indexation.

Finally, the signature of an industry-level agreement has a negative effect on the probability of a firm-level agreement. However a systematic relationship between the frequency of industry-level and firm-level agreements cannot be easily established (see below). It seems that small firms are more likely to be covered by an industry-level agreement while larger firms are more often covered by a firm-level agreement. Besides, firm-level wage agreements are more frequent in firms where we 
observe an increase in profitability, all other things being equal. An increase in the local unemployment rate significantly decreases the frequency of firm-level agreements. The probability of a firm-level wage agreement is partly explained by state variables, which is in line with the predictions of state-dependent models.

[Tables 4 and 5]

\section{The timing of wage agreements}

In most macroeconomic models, wage changes are supposed to be staggered (Taylor, 1980, and Calvo, 1983). The staggering or the synchronization of wage changes is shown to have an impact on the real effects of the monetary policy. Olivei and Tenreyro (2007) show that, in the United States, the output responds more quickly to monetary policy occurring in the first months of the year, and they explain this finding by a strong seasonality of wage agreements. ${ }^{16}$ According to Olivei and Tenreyro (2010), in some European countries, wage agreements are more staggered over the year and the timing effects of monetary policy shocks are thus less significant. However, De Walque et al. (2010) find that timing effects are significant in the euro area where a lot of wage changes are clustered at the beginning of the year. In this section, we investigate the degree of staggering or synchronization of wage changes by examining the seasonality of wage agreements.

\subsection{Seasonality of wage change decisions}

Table 6 reports the monthly proportion of wage agreements at both the industry and firm levels and the monthly frequency of wage change decisions (including minimum wage changes).

[Table 6]

First, industry-level agreements are highly seasonal. About 55 percent of agreements are signed between October and January with a maximum (20 percent) in December. By contrast, only few industry-level agreements are signed in February, March, August and September (a little more than 4 percent of agreements each month on average). The timetable of firm-level agreements is rather delayed compared to the timetable of industry-level agreements. Firm-level agreements are most frequently signed between December and April (more than 60 percent of agreements are signed during this five-month period) with a peak between March and April (more than 25 percent of wage agreements). The proportion of wage agreements is only 27.5 percent between May and July and less than 15 percent between August and November. This sequence of wage agreements is explained by the hierarchy between the two levels of wage bargaining. Industry-level wage agreements are more likely to be signed at the end of the year, and once the industry-level agreement is observed, firms agree on wages at the beginning of the following year.

These two slightly different timetables make wage change decisions rather staggered over the year. The frequency of wage change decisions is close to its average ( 9.5 percent) all over the year. Two exceptions are December and July where the frequency of wage changes is about 20 percent. The first seasonal peak is linked to wage changes implied by industry- and firm-level agreements, whereas the second is linked to the NMW annual revision. We also observe wage changes in August and September.

\subsection{Seasonality of effective wage changes}

Many wage agreements come into force in specific months of the year and the frequency of wage agreement effects is more seasonal (Table 6). At the industry level, a little less than 40 percent of wage agreements come into force in January. Two smaller peaks are observed in July and October where

\footnotetext{
${ }^{16}$ Dupor and Han (2009) challenge somewhat this result but they still find a timing effect for monetary shocks.
} 
about 15 percent and 12 percent of wage agreements are implemented, respectively. In other months, on average, only 4 percent of wage agreements come into force. At the firm level, the synchronisation of wage changes shows similar patterns with peaks in January (20.6 percent of wage agreements becoming effective during this month), July and October (10 and 11 percent, respectively). However, another peak is observed between March and April (23.5 percent of wage agreements becoming effective during this two-month period).

The frequency of wage changes reflects this strong seasonality (Table 6). The frequency of effective wage changes is much higher than its average in January and July (36.2 percent and 26.9 percent of wage changes versus 10 percent on average). Two smaller peaks are observed in April and October (about 10 percent of wage changes) whereas in other months the frequency of wage changes is on average less than 5 percent. ${ }^{17}$ The seasonality of observed wage changes is slightly different from the one that could be inferred from the seasonality of wage agreements. Effective wage changes are less staggered than wage change decisions. Interestingly, this seasonality in wage changes translates in aggregate wage series. The quarterly aggregate wage growth in France is seasonal. On average it is larger in the first and the third quarters ( 0.75 percent and 0.61 percent) where wage changes are more frequent, the aggregate wage growth being slightly smaller $(0.58 \text { percent })^{18}$ and much lower in the fourth quarter (0.35 percent). By comparison, Barattieri et al. (2009) find no significant seasonality in wage changes in the United States.

Another noticeable finding is that the seasonality of wage bargaining also mirrors the seasonal pattern of producer price adjustments. Gautier (2008) finds that, in France, the proportion of producer price changes is larger in January and, to a lesser extent, in July and April. ${ }^{19}$ This may suggest simultaneous price- and wage-setting decisions at the firm level.

\subsection{Interplays of timetables at the different levels of wage bargaining}

We examine in this section the links between the timetables of the different stages of wage bargaining. In theory, the links between industry- and firm-level agreements are clearly defined, according to the principle of the most favorable settlement. This hierarchy should have an impact on the degree of synchronization of agreements since industry-level agreements should come first, before firm-level agreements. In practice, however, bargaining calendars are not systematically linked.

Figure 3 represents the timetables of wage agreements in two different industries, namely the chemical and the road haulage industries. We plot on the same graph the dates of signature and the dates of implementation of industry-level agreements (vertical lines) and the number of firm-level wage agreements (grey histograms). In the chemical industry, the link between industry- and firmlevel agreements is quite clear. The majority of industry agreements are negotiated in November or December, and take effect at the beginning of the following year, often in January. In this industry, most of the firm-level agreements are signed between February and March. In 2005, the absence of an industry-level agreement leads to a higher frequency of firm-level agreements. This example is quite typical of the seasonality that we have documented in the previous section. In the road haulage industry, the majority of industry-level agreements take effect in July and August whereas firm-level agreements do not follow any regular timetable. This reflects the influence of the annual revision of the minimum wage level in this industry. So, at the end of the observation period, when the minimum

\footnotetext{
${ }^{17}$ Using survey evidence from firms in the euro area, Druant et al. (2009) find that wage changes are clustered in some specific months (i.e. January, July and April).

18 The difference in average aggregate wage changes between the second and the third quarters is even stronger for blue collar workers $(0.72$ percent in the third quarter versus 0.65 percent in the second quarter).

${ }^{19}$ Similar findings are obtained at the euro area level by Vermeulen et al. (2007).
} 
wage rose significantly, the number of firm-level agreements increased, even though there were no industry agreements.

[Figure 3]

The annual increase in the NMW level has also a significant impact on the industry- and the firmlevel bargaining calendars. To assess the effect of the NMW on the wage agreement timetable, we use the following random-effect Probit models:

$$
\begin{aligned}
& y_{i t}^{m}=1 \text { if } y_{i t}^{m^{*}}>0, y_{i t}^{m}=0 \text { otherwise, } \\
& \text { with } y_{i t}^{m^{*}}=x_{i t}+v_{i}+\varepsilon_{i t}^{m}
\end{aligned}
$$

where $y_{i t}^{m}$ is a dummy variable taking the value 1 if an agreement is signed in the firm (respectively, in the industry) $i$ in year $t$ and in month $m$, and the value 0 if the agreement is signed in a different month $\left(m^{\prime}=m\right)$. For a given industry or firm $i, x_{i t}$ is a set of covariates including the proportion of days paid the NMW in year $t$ at both the local and industry levels, and other controls. The $v_{i}$ 's are industryor firm-specific random effects, and $\varepsilon_{i t}$ are random exogenous shocks normally distributed with mean 0 and variance 1 . We estimate a model for each month of the year, separately for the dates of signature and the dates of effect of agreements.

Table 7 reports the marginal effects of the proportion of days paid the NMW. At the firm level, agreements are less often signed at the beginning and at the end of the year if the NMW covers a large share of the labor force. When the NMW covers a large part of the labor force, agreements are more likely to be signed between June and September. ${ }^{20}$ If we now consider the dates of effect of firm-level agreements, we obtain similar results, namely a higher frequency of wage agreements in July, when the NMW is revised, and a lower frequency in January and March. The results are relatively less significant for industry-level agreements, but the proportion of days paid the NMW also affects the agreement calendar: when this proportion is higher, agreements are more often signed in September and take effect more frequently at the end rather than at the beginning of the year. Since 2010, the NMW is revised in January, which might increase the number of agreements signed at the beginning of the year.

\section{[Table 7]}

\section{The size of wage changes in collective agreements}

We here provide some stylized facts on the size of wage changes in industry- and firm-level agreements. One main objective of this section is to identify some of the determinants of the size of nominal wage changes. To assess the main factors driving the distribution of wage changes, we use a downward nominal wage rigidity model (i.e. we account for the large proportion of zero wage changes in the distribution) following Dickens et al. (2007), Christofides and Stengos (2003) and Christofides and $\mathrm{Li}(2005) .{ }^{21}$ By law, collective wage decreases are impossible in France: they can only be decided at the firm level in case of strong difficulties. Thus we focus here on the distribution of negotiated wage increases.

\footnotetext{
${ }^{20}$ Further regressions show that this effect is even stronger between 2003 and 2005 when the NMW rose significantly.

${ }^{21}$ In our data set, information on wage increases negotiated in firm-level agreements is available for the sub-period going from 1994 to 2001 . At the industry level, the only available data cover the sub-period going from 1999 to 2005 . In this case, the increases are calculated as the averages of the different increases negotiated for the industry wage grid.
} 


\subsection{Cross-section analysis of negotiated wage increases}

Table 8 reports descriptive statistics on the average wage increase negotiated in both industry- and firm-level agreements. The annual negotiated wage increase is quite high (close to 3.5 percent) whereas the aggregate average wage increase in the private sector is closer to 2.5 percent during the same period. At the industry level, wage bargaining frequently deals with monthly or annual wage scales. So, if in a given year no agreement is signed, the previous pay scale still applies and the next agreement should catch up, taking into account past inflation or past NMW increases. As a result, the observed negotiated increases depend on the duration between two successive agreements and on the catching up constraint. The average wage change increase per year since the last agreement is close to 2.5 percent. Figure 4 displays the distribution of wage increases in industry-level agreements. The distribution is rather widespread and modes are observed at 2 and 2.5 percent. Large wage increases are not rare: 25 percent of industry-agreements contain wage increases above 3.3 percent (Table 8 ).

[Table 8]

At the firm level, the average wage increase is smaller (about 1.5 percent). Most agreements stipulate wage increases that are expressed in percentage rather than in terms of grid thresholds specific to firms. Moreover, some agreements can imply a different wage increase for each occupation. For those agreements, wage increases for blue collar workers are slightly higher than for other workers. On Figure 4, the distribution of wage changes at the firm level exhibits a smaller dispersion than at the industry level. Besides, 14.9, 10.4 and 16 percent of wage changes are exactly equal to 1 , 1.5 and 2 percent, respectively. This may reflect psychological-threshold wage increases which are less significant in industry-level agreements.

\section{[Figure 4]}

\subsection{Negotiated wage increases over time}

On Figure 5, we plot the yearly average wage increase negotiated both at industry and firm levels. At the industry level (except in year 1999) wages have increased between 2.5 and 3 percent. If we compare those statistics with the aggregate base wage growth in the private sector calculated by the French Ministry of Labor, both series show fairly strong correlation. The larger increase in 2005 can be explained by the sharp rise in the NMW the same year (the NMW rose by more than 5 percent between 2003 and 2005). In several industries, the negotiated increases correspond exactly to the raises in the minimum wage level, and a catch-up phenomenon is observed in several collective agreements. ${ }^{22}$ Increases in the highest parts of the pay scales are lower. Since minimum wage increases are indexed to past inflation, industry-level wage increases appear to be correlated with other wages and past inflation.

[Figure 5]

At the firm level, the average negotiated wage increases ranges between 1 and 2 percent from 1994 to 2001 and is positively correlated with the inflation rate (Figure 5). In some macroeconomic models, it is assumed that wages are indexed to past inflation. This correlation may then support the existence of such an indexation mechanism. We can also note that if the average wage increase at the firm level follows closely the inflation rate between 1994 and 1997, wage increases are relatively higher than inflation in years 1998 and 1999 when the inflation rate is close to 0 percent.

\subsection{Some determinants of wage increases}

\footnotetext{
${ }^{22}$ For example, in the "Soil, Products and Fertiliser" or "Fast Food" industries, which negotiated regularly between 2003 and 2005 , the lower part of the wage scale is equal to the minimum wage level, and the negotiated increase at this lower part is equal to the rise in the minimum wage level.
} 
We now estimate a simple model of downward nominal wage rigidity to identify the main determinants of negotiated increases at the firm and industry levels. For that purpose, we use a Tobit-1 model. The dependent variable $\Delta w_{i t}$ is the negotiated wage increase stipulated by the firm- or the industry-level agreement. By definition, it is equal to 0 if there is no wage agreement or if the negotiated wage increase is equal to 0 (as in many agreements dealing simultaneously with wages and with working time reduction). We assume that the wage increase $\Delta w_{i t}$ in year $t$, in the firm or industry $i$, is generated by the following latent variable:

$$
\Delta w_{i t}^{*}=\beta x_{i t}+u_{i}+\varepsilon_{i t}
$$

where $x_{i t}$ is a vector of covariates which includes $(i)$ for an industry $i$, the elapsed duration since the last agreement, the proportion of days paid the NMW in this industry, the proportion of firms with less than 50 workers in this industry, a dummy for services versus manufacturing sector; (ii) for a firm $i$, it includes the annual growth of profitability per worker, the annual variation in the local unemployment rate at the département level, the proportion of days paid the NMW in the industry and in the département where the firm is localized, dummy variables indicating if an industry level agreement has been signed the same year, the year before, etc. and the size of the firm. $\beta$ is a vector of parameters associated with $x_{i t}, u_{i}$ is a random effect specific to firm or to industry $i$ (normally distributed with mean 0 and variance $\sigma_{u}^{2}$ ), and $\varepsilon_{i t}$ is normally distributed with mean 0 and variance $\sigma_{e}^{2} . \rho$ is the correlation coefficient between $u_{i}$ and $\varepsilon_{i t}$. The model is the following:

$$
\begin{gathered}
\Delta w_{i t}=\Delta w_{i t}^{*} \text { if } \Delta w_{i t}^{*}>0 \\
\Delta w_{i t}=0 \text { if } \Delta w_{i t}^{*} \leq 0{ }^{23}
\end{gathered}
$$

Table 5 reports the estimation results for industry-level agreements. First, we find that the duration since the last agreement has a large positive effect on the wage change, which may capture a catching up effect. Contrary to estimates obtained for the Logit model, we here obtain that the proportion of small firms in the industry has a clear significant positive effect on the negotiated pay raise. Moreover, the larger the proportion of days compensated close to the minimum wage level, the higher the increase negotiated in the industry. These last two observations reinforce our previous findings. Industry-level agreements deal mostly with low wages close to the minimum wage. Most of the lowpaid workers are in small firms, and small firms are particularly concerned with industry-level negotiations because they are less costly than firm-level agreements. As a result, NMW increases have an impact on wage increases at the industry level and could create a significant indexation mechanism (Gray, 1978).

Table 6 reports the estimation results for firm-level agreements. A significant determinant of wage increases is the firm's performance but its impact is quite weak (see Manning, 2010, for a survey). However, our findings are consistent with those obtained by Biscourp et al. (2005) who estimate a similar model using data on actual wages. The variation of the local unemployment rate has an unexpected positive significant effect but this effect is negative during the period 1994-1997. The proportion of working days paid close to the NMW has a significant negative impact on wage changes. The size of the firm affects positively both the negotiated wage increase and its effect is large. Contrary to industry-level agreements, firm-level agreements are more likely to cover highwage workers and large firms. A previous industry-level wage agreement has a positive impact on the

\footnotetext{
${ }^{23}$ We assume here that there is no measurement error as we observe the average wage increase stipulated by the agreement.
} 
firm level wage increases. Since there is a hierarchy between the different levels of wage bargaining, a firm-level wage increase adds to the already negotiated industry-level wage increase.

\section{Conclusion}

Using unique data sets on wage agreements at both firm and industry levels in France, we document some stylized facts on wage rigidity. We also assess the empirical validity of usual wage rigidity models. We finally examine to which extent the French institutional wage setting framework has an impact on the degree of wage rigidity.

Our main results are the following. First, 10 percent of wages are modified by a wage agreement each month and the average duration between two wage changes is around 10 months. The distribution of durations between two wage decisions shows a large peak at 12 months whereas the distribution of effective wage changes exhibits two peaks at 3 and 6 months. Except at 6, 12 and 24 months, the hazard rate is rather flat. A simple Calvo (1983) model cannot replicate such distributions of wage durations. We need to assume some heterogeneity in wage-setting models across firms. The peak at 12 months supports the existence of fixed duration wage contracts à la Taylor (1980), whereas the flatness of the hazard rate is consistent with the predictions of a model $a ̀$ la Calvo (1983). Moreover, we find some evidence in favor of the predetermination of wage-setting: 44 percent of firm-level agreements and 18 percent of industry-level agreements contain more than one wage increase. This finding is consistent with predictions set forth by Fischer (1977). However, these predetermined wage changes take effect mostly during the year following the signature of the agreement, which makes the impact of predetermination on macro-dynamics rather limited. Thirdly, the wage change decisions are rather staggered over the year: industries bargain on wages between October and January and firms negotiate during the first months of the year, which implies a rather flat frequency of wage change agreements over the year. Effective wage changes are more synchronized in some specific months, namely January and July, and to a lesser extent in April and October. Lastly, the distributions of negotiated wage increases depend on the inflation rate for firms and on the aggregate wage and NMW increases for industries, which might indicate the existence of indexation mechanisms.

Wage-setting institutions have a significant impact on wage rigidity. There are complex interactions between the different levels of the bargaining process. It appears that the industry-level agreements are more likely to be binding for low-paid workers and for small firms. The firm-level agreements cover more frequently larger firms and high-wage workers. The national minimum wage (NMW) plays a significant role in explaining the occurrence of a wage agreement. Its impact is negative on firm-level agreements and positive on industry-level agreements. The NMW has also a significant effect on the timing of the wage agreements and on the frequency of wage changes. 


\section{References}

Aghion, Philippe, Yann Algan and Pierre Cahuc, "Civil Society and the State: the Interplay between Cooperation and Minimum Wage," Journal of the European Economic Association 9 (2011), 3-42.

Amossé, Thomas, and Maria-Teresa Pignoni, "La transformation du paysage syndical depuis 1945" (pp. 405-414), in Données sociales 2006 (Paris: INSEE, 2006).

Barattieri, Alessandro, Susanto Basu and Peter Gottschalk, "Some Evidence on the Importance of StickyWages," Boston College, manuscript (2009).

Biscourp, Pierre, Nathalie Fourcade and Odetta Dessy, "Les salaires sont-ils rigides? Le cas de la France à la fin des années 1990," Économie et Statistique 386 (2005), 59-89.

Calvo, Guillermo A., "Staggered Prices in a Utility Maximizing Framework," Journal of Monetary Economics 12 (1983), 383-398.

Cecchetti, Stephen, "Indexation and Incomes Policy: a Study of Wage Adjustment in Unionized Manufacturing," Journal of Labor Economics 5 (1987), 391-412.

Chamberlain, Gary, "Panel Data" (pp. 1247-1318), in Zvi Griliches and Michael D. Intriligator (Eds.), Handbook of Econometrics, vol. 2 (Amsterdam: North Holland, 1984).

Christofides, Louis, and Audrey Laporte, "Menu Costs, Nominal Wage Revisions, and Intracontract Wage Behavior," Industrial Relations 41 (2002), 287-301.

Christofides, Louis, and Dingding Li, "Nominal and Real Wage Rigidity in a Friction Model," Economics Letters 87 (2005), 235-241.

Christofides, Louis, and Thanasis Stengos, "Wage Rigidity in Canadian Collective Bargaining Agreements," Industrial and Labor Relations Review 56 (2003), 429-448.

Christofides, Louis, and David Wilton, "The Empirical Determinants of Contract Length", Journal of Monetary Economics 12 (1983), 309-319.

Christiano, Lawrence J., Martin Eichenbaum and Charles Evans, "Nominal Shocks and the Dynamic Effects of a Shock to Monetary Policy," Journal of Political Economy 113 (2005), 1-45.

Danziger, Leif, and Shoshana Neuman, "Delays in Renewal of Labor Contracts: Theory and Evidence," Journal of Labor Economics 23(2) (2005), 341-371.

De Walque, Grégory, Juan Jimeno, Michael Krause, Hervé Le Bihan, Stephen Millard, and Frank Smets, "Some Macroeconomic and Monetary Policy Implications of New Micro Evidence on Wage Dynamics," Journal of European Economic Association 8 (2010), 506-513.

Dickens, William T., Lorenz Goette, Erica L. Groshen, Steinar Holden, Julian Messina, Mark E. Schweitzer, Jarkko Turunen, and Melanie E. Ward, "How Wages Change: Micro Evidence from the International Wage Flexibility Project," Journal of Economic Perspectives 21 (2007), 195-214.

Druant, Martine, Silvia Fabiani, Gabor Kezdi, Ana Lamo, Fernando Martins, and Roberto Sabattini, "How are Firms' Wages and Prices Linked: Survey Evidence in Europe," ECB working paper no. 1084 (2009).

Du Caju, Philip, Erwan Gautier, Daphne Momferatou, and Melanie Ward-Warmedinger, "Institutional Features of Wage Bargaining in 23 European Countries, the US and Japan," Ekonomia 12(2) (2009), 57-108.

Dupor, Bill, and Jing Han, "A Search for Timing Effects of Macroeconomic Shocks in the U.S.," Ohio State University, mimeo (2009).

Erceg, Christopher J., Dale W. Henderson, and Andrew T. Levin, "Optimal Monetary Policy with Staggered Wage and Price Contracts," Journal of Monetary Economics 46 (2000), 281-313.

Fischer, Stanley, "Long-term Contracts, Rational Expectations, and the Optimal Money Supply Rule", Journal of Political Economy 85 (1977), 191-205. 
Fougère, Denis, Erwan Gautier, and Hervé Le Bihan, "Restaurant Prices and the Minimum Wage," Journal of Money, Credit and Banking 42(7) (2010), 1199-1234.

Fougère, Denis, Hervé Le Bihan, and Patrick Sevestre, "Heterogeneity in Consumer Price Stickiness: A Microeconometric Investigation," Journal of Business and Economic Statistics 25 (2007), 247-264.

Gali, Jordi, "Monetary Policy and Unemployment," (pp. 487-546), in B. Friedman and M. Woodford (Eds.), Handbook of Monetary Economics, vol. 3A (Amsterdam: Elsevier, 2011).

Gautier, Erwan, "The Behaviour of Producer Prices: Evidence from French PPI Micro-Data," Empirical Economics 35 (2008), 301 - 332.

Gray, Jo A., “On Indexation and Contract Length,” Journal of Political Economy 86 (1978), 1-18.

Gu Wulong, and Peter Kuhn, "A Theory of Holdouts in Wage Bargaining," American Economic Review 88(3) (1998), 428-449.

Guertzgen, Nicole, "Rent-Sharing and Collective Bargaining Coverage: Evidence from Linked Employer-Employee Data," Scandinavian Journal of Economics 111(2) (2009), 323-349.

Heckel, Thomas, Hervé Le Bihan, and Jérémi Montornès, "Sticky Wages: Evidence from Quarterly Microeconomic Data," ECB Working Paper no. 893 (2008).

Huang, Kevin X. D., and Zheng Liu, "Staggered Price-Setting, Staggered Wage-Setting, and Business Cycle Persistence," Journal of Monetary Economics 49 (2002), 405-433.

Klenow, Peter, and Benjamin Malin, "Microeconomic Evidence on Price-Setting," (pp. 231-284), in B. Friedman and M. Woodford (Eds.), Handbook of Monetary Economics, vol. 3A (Elsevier, Amsterdam, Holland, 2011).

Manning, Alan, "Imperfect Competition in Labour Markets," (pp. 973-1041) in O. Ashenfelter and D. Card, (Eds.), Handbook of Labor Economics, vol. 4B (Elsevier, Amsterdam, Holland, 2010).

Olivei, Giovanni, and Silvana Tenreyro, "The Timing of Monetary Policy Shocks," American Economic Review 97 (2007), 636-663.

Olivei, Giovanni, and Silvana Tenreyro, "Wage Setting Patterns and Monetary Policy: International Evidence," Journal of Monetary Economics 57 (2010), 785-802.

Taylor, John B., "Aggregate Dynamics and Staggered Contracts," Journal of Political Economy 88 (1980), 1-23.

Taylor, John B., "Union Wage Settlements during a Disinflation," American Economic Review 73 (1983), 981-993.

Taylor, John B., "Staggered Price and Wage Setting in Macroeconomics" (pp. 1009-1050), in John B. Taylor and Michael Woodford (Eds.), Handbook of Macroeconomics, vol. 1B (Amsterdam: NorthHolland, 1999).

Vermeulen Philip, Daniel Dias, Maarten Dossche, Erwan Gautier, Ignacio Hernando, Roberto Sabbatini, and Harald Stahl, "Price Setting in the euro area: some Stylized Facts from Producer Price Data," ECB Working paper No 727 (2007). 
Table 1: Duration and frequency of wage agreements

\section{Mean $\quad 1^{\text {st }}$ quartile $\quad$ Median $\quad 3^{\text {rd }}$ quartile}

Duration (in months)

\begin{tabular}{lllll} 
Agreements & 9.4 & 4 & 8 & 12 \\
Effects & 8.7 & 3 & 6 & 12 \\
\hline
\end{tabular}

Frequency (in percent)

\begin{tabular}{lllll} 
Agreements & 9.6 & 7.9 & 9.5 & 12.4 \\
Effects & 9.9 & 8.3 & 9.6 & 12.8 \\
\hline
\end{tabular}

Implied duration (in months)

\begin{tabular}{lcccc} 
Agreements & 10.4 & 8.1 & 10.5 & 12.6 \\
Effects & 10.1 & 7.8 & 10.5 & 12.1 \\
\hline
\end{tabular}

The variable used for computing these statistics is equal to one if workers in a given firm are covered by a wage agreement (resp., by the effect) at the firm- or-industry-levels, or by the NMW increase. All statistics are weighted by the number of workers in each firm and by the number of workers paid close to the NMW. The frequency of wage changes is reported in percentages per month and are first calculated at the disaggregate industry level. Durations are computed as the difference between two successive agreements or two successive effects (either an industry-or a firm-level agreement or an increase in the NMW). Statistics on durations are reported in months and are computed only for non-censored observations. Implied durations are computed as the inverse of the monthly frequency of wage changes. Statistics concerning agreements are computed over the period 1994-2005 whereas statistics concerning effects are calculated for the period 1994-2001. 
Table 2: Frequency and duration of wage agreements by firm size and by industry

\begin{tabular}{|c|c|c|c|c|}
\hline & \multicolumn{2}{|c|}{ Agreement } & \multicolumn{2}{|c|}{ Effect } \\
\hline & Frequency & $\begin{array}{l}\text { Implied } \\
\text { duration }\end{array}$ & Frequency & $\begin{array}{l}\text { Implied } \\
\text { duration }\end{array}$ \\
\hline & (in percent) & (in months) & (in percent) & (in months) \\
\hline \multicolumn{5}{|c|}{ Size (number of workers) } \\
\hline $0-20$ & 7.3 & 13.7 & 8.9 & 11.2 \\
\hline $20-50$ & 7.6 & 13.2 & 9.3 & 10.8 \\
\hline $50-100$ & 7.8 & 12.8 & 9.3 & 10.7 \\
\hline $100-200$ & 8.4 & 12.0 & 9.7 & 10.3 \\
\hline $200-500$ & 9.4 & 10.7 & 10.1 & 9.9 \\
\hline more than 500 & 12.2 & 8.2 & 10.7 & 9.4 \\
\hline \multicolumn{5}{|l|}{ Industry } \\
\hline Agriculture & 8.7 & 11.5 & 8.3 & 12.0 \\
\hline Manufacturing & 10.8 & 9.3 & 10.4 & 9.6 \\
\hline Construction & 8.3 & 12.0 & 7.4 & 13.6 \\
\hline Services & 8.8 & 11.4 & 10.2 & 9.8 \\
\hline
\end{tabular}

The variable used for computing these statistics is equal to one if workers in a given firm are covered by a wage agreement (resp. the effect of a wage agreement) at the firm-or-industry-levels or by the NMW increase. All statistics are weighted by the number of workers in each firm and by the number of workers paid close to the NMW. The frequency of wage changes is reported in percentages per month and are first calculated at the disaggregate industry level. Implied durations are computed as the inverse of the monthly frequency of wage changes. Statistics for agreements are computed over the period 1994-2005 whereas statistics for effects are calculated over the period 1994-2001. 
Table 3: Duration between the date of signature of the wage agreement and the date at which it takes effect (in months)

\section{Number of Proportion of \\ wage increases agreements \\ Mean $1^{\text {st }}$ quartile Median $3^{\text {rd }}$ quartile}

Industry-level agreement

$\begin{array}{llllll}\mathbf{1} & 1.00 & -0.1 & -1 & 1 & 2 \\ \mathbf{2} & 0.18 & 5.9 & 4 & 6 & 8 \\ \mathbf{3} & 0.02 & 10 & 5 & 8 & 12\end{array}$

Firm- level agreement

$\begin{array}{llllll}\mathbf{1} & 1.00 & 0.1 & -1 & 0 & 1 \\ \mathbf{2} & 0.44 & 5.2 & 4 & 6 & 7 \\ 3 & 0.09 & 7.8 & 5 & 7 & 9\end{array}$

The first column reports the number of wage increases stipulated in the wage agreement. The second column is the proportion of wage agreements containing at least one, two or three wage increases; for instance, 44\% of firm-agreements contain at least two wage increase. Other columns report some statistics on the durations between the date of agreement and the different dates of effect. For firms, results are obtained for the period 1994-2001 whereas, for industries, they are obtained for the period 1994-2005. 
Table 4: Determinants of the occurrence and of the average wage increase negotiated in industry-level wage agreements (parameter estimates)

\begin{tabular}{|c|c|c|c|c|}
\hline & \multicolumn{2}{|c|}{ Probit } & \multicolumn{2}{|c|}{ Tobit } \\
\hline & Agreement & Effect & Agreement & Effect \\
\hline Intercept & $\begin{array}{l}0.499^{* *} \\
(0.219)\end{array}$ & $\begin{array}{l}-0.413^{*} \\
(0.215)\end{array}$ & $\begin{array}{c}-6.721^{* *} \\
(0.740)\end{array}$ & $\begin{array}{c}-6.457^{* *} \\
(0.714)\end{array}$ \\
\hline \multicolumn{5}{|l|}{ Duration since the last agreement: } \\
\hline - 1 year & $\begin{array}{c}0.252^{* *} \\
(0.122)\end{array}$ & $\begin{array}{c}0.430^{* *} \\
(0.117)\end{array}$ & $\begin{array}{c}1.252^{* *} \\
(0.539)\end{array}$ & $\begin{array}{c}1.217^{* *} \\
(0.505)\end{array}$ \\
\hline - 2 years & $\begin{array}{c}0.379^{* * *} \\
(0.125)\end{array}$ & $\begin{array}{c}0.398^{* * *} \\
(0.124)\end{array}$ & $\begin{array}{c}1.853^{* *} \\
(0.528)\end{array}$ & $\begin{array}{c}1.699^{* * *} \\
(0.500)\end{array}$ \\
\hline - 3 years & $\begin{array}{l}0.216 \\
(0.150)\end{array}$ & $\begin{array}{l}0.410^{* *} \\
(0.149)\end{array}$ & $\begin{array}{l}1.919^{* *} \\
(0.585)\end{array}$ & $\begin{array}{l}1.831^{* *} \\
(0.562)\end{array}$ \\
\hline - $\quad$ More than 3 years & Ref. & Ref. & Ref. & Ref. \\
\hline $\begin{array}{l}\text { Proportion of days paid the minimum } \\
\text { wage }\end{array}$ & $\begin{array}{l}0.001 \\
(0.005)\end{array}$ & $\begin{array}{l}0.004 \\
(0.005)\end{array}$ & $\begin{array}{c}0.033^{* *} \\
(0.014)\end{array}$ & $\begin{array}{l}0.030^{* *} \\
(0.014)\end{array}$ \\
\hline $\begin{array}{l}\text { Proportion of firms with less than } 50 \\
\text { workers }\end{array}$ & $\begin{array}{c}0.005^{* *} \\
(0.002)\end{array}$ & $\begin{array}{l}0.003 \\
(0.002)\end{array}$ & $\begin{array}{l}0.016^{* *} \\
(0.006)\end{array}$ & $\begin{array}{l}0.012^{* *} \\
(0.006)\end{array}$ \\
\hline Manufacturing & Ref. & Ref. & Ref. & Ref. \\
\hline Services & $\begin{array}{r}-0.217^{*} \\
(0.129)\end{array}$ & $\begin{array}{l}-0.107 \\
(0.121)\end{array}$ & $\begin{array}{l}-0.869^{* *} \\
(0.352)\end{array}$ & $\begin{array}{r}-0.600^{*} \\
(0.344)\end{array}$ \\
\hline$\sigma_{u}$ & $\begin{array}{c}0.498^{* * *} \\
(0.053)\end{array}$ & $\begin{array}{c}0.466^{* *} \\
(0.050)\end{array}$ & $\begin{array}{c}0.750^{* *} \\
(0.275)\end{array}$ & $\begin{array}{c}0.875^{* *} \\
(0.224)\end{array}$ \\
\hline$\sigma_{\varepsilon}$ & & & $\begin{array}{l}3.798^{* *} \\
(0.114)\end{array}$ & $\begin{array}{l}3.643^{* *} \\
(0.107)\end{array}$ \\
\hline$\rho$ & & & $\begin{array}{l}0.038 \\
(0.027) \\
\end{array}$ & $\begin{array}{l}0.055 \\
(0.027) \\
\end{array}$ \\
\hline Sample period & 1994-2005 & 1994-2005 & $1999-2005$ & 1999-2005 \\
\hline Observations & 2,436 & 2,639 & 1,896 & 1,747 \\
\hline
\end{tabular}

The proportion of days paid the minimum wage is calculated as the number of days paid around the minimum wage in each industry and in each département a given year, divided by the total number of days paid in the same industry and in the same département the same year, whatever the wage level. The proportion of firms with less than 50 workers is calculated as the number of firms with less than 50 workers divided by the total number of firms in the industry. Other control variables include year and size dummies, and a dummy variable indicating whether the agreement stipulates a reduction in the number of workweek hours.

Symbols: **: significant at the 5 percent level, *: significant at the 10 percent level (otherwise, statistically non-significant). Standard errors are in brackets 
Table 5: Determinants of the occurrence and of the average wage increase negotiated in firmlevel wage agreements (parameter estimates)

\begin{tabular}{|c|c|c|}
\hline & Logit & Tobit \\
\hline Intercept & - & $\begin{array}{c}-6.959^{* *} \\
(0.293)\end{array}$ \\
\hline Annual variation of profitability between years $t-1$ and $t$ & $\begin{array}{c}0.001^{* *} \\
(0.000)\end{array}$ & $\begin{array}{c}0.006^{* * *} \\
(0.001)\end{array}$ \\
\hline Annual variation of profitability between years $t-2$ and $t-1$ & $\begin{array}{c}0.004^{* *} \\
(0.000)\end{array}$ & $\begin{array}{c}0.005^{\text {** }} \\
(0.001)\end{array}$ \\
\hline Proportion of days paid around the minimum wage & $\begin{array}{c}-0.021^{* *} \\
(0.000)\end{array}$ & $\begin{array}{c}-0.025^{* * *} \\
(0.003)\end{array}$ \\
\hline Variation of the annual local unemployment rate & $\begin{array}{c}-0.005^{* *} \\
(0.000)\end{array}$ & $\begin{array}{l}0.014^{* *} \\
(0.003)\end{array}$ \\
\hline \multicolumn{3}{|l|}{ Size of the firm } \\
\hline -between 50 and 100 workers & Ref. & Ref. \\
\hline -between 100 and 200 workers & $\begin{array}{c}0.412^{* *} \\
(0.005)\end{array}$ & $\begin{array}{c}1.734^{* *} \\
(0.079)\end{array}$ \\
\hline -between 200 and 500 workers & $\begin{array}{c}0.893^{* * *} \\
(0.006)\end{array}$ & $\begin{array}{l}3.016^{* * *} \\
(0.091)\end{array}$ \\
\hline -more than 500 workers & $\begin{array}{c}1.427^{* * *} \\
(0.007)\end{array}$ & $\begin{array}{c}4.045^{* * *} \\
(0.111)\end{array}$ \\
\hline
\end{tabular}

Occurrence of an industry-level agreement

-the same year

$-0.115^{* *}$

$0.324^{* *}$

$(0.003)$

$-0.167^{* * *}$

$(0.120)$

-last year

$(0.003)$

$0.348^{* * *}$

$-0.124^{* * *}$

-two years ago

(0.004)

$0.344 * *$

(0.144)

-more than two years ago

Ref.

Ref.

$$
\begin{gathered}
\sigma_{u} \\
\sigma_{\varepsilon} \\
\rho
\end{gathered}
$$$$
2.593^{* *}
$$$$
0.548^{* *}
$$$$
\text { (0.009) }
$$

Sample period

1994-2005

1994-2001

Observations

51,282

97,478

The proportion of days paid the minimum wage is calculated as the number of days paid around the minimum wage in each industry and in each département a given year, divided by the total number of days paid in the same industry and in the same département the same year, whatever the wage level. The local unemployment rate variation is computed at the département level each year. Year dummies, industry dummies and a dummy variable indicating that the agreement concerns also the reduction of the workweek duration are included.

Symbols: **: significant at the 5 percent level, *: significant at the 10 percent level (otherwise, statistically non-significant). Standard errors are between brackets

In the conditional logit model (see Chamberlain, 1984), we keep only the subsample of "movers" (i.e. only those firms for which the variable $y_{i t}$ takes both the values 0 and 1 over the observation period), whereas the random effect probit model is estimated using the whole sample. 
Table 6: Timing of industry-level and firm-level wage agreements and of their effects

\begin{tabular}{|c|c|c|c|c|c|c|}
\hline & \multicolumn{3}{|c|}{ Agreement } & \multicolumn{3}{|c|}{ Effect } \\
\hline & \multicolumn{2}{|l|}{$\begin{array}{l}\text { Proportion of } \\
\text { agreements } \\
\quad \text { (in percent) }\end{array}$} & \multirow[t]{2}{*}{$\begin{array}{l}\text { Freq. of wage } \\
\text { changes } \\
\text { (in percent) }\end{array}$} & \multicolumn{2}{|c|}{$\begin{array}{l}\text { Proportion of } \\
\text { agreements } \\
\quad \text { (in percent) }\end{array}$} & \multirow[t]{2}{*}{$\begin{array}{c}\text { Freq. of wage } \\
\text { changes } \\
\text { (in percent) }\end{array}$} \\
\hline & Industry & Firm & & Industry & Firm & \\
\hline January & 9.5 & 10.6 & 9.4 & 37.5 & 20.6 & 36.2 \\
\hline February & 4.9 & 12.1 & 7.6 & 3.7 & 6.1 & 4.6 \\
\hline March & 6.0 & 13.6 & 8.4 & 5.0 & 10.0 & 7.0 \\
\hline April & 8.3 & 13.0 & 9.8 & 6.8 & 13.5 & 10.2 \\
\hline May & 6.7 & 8.7 & 8.7 & 3.1 & 5.1 & 4.6 \\
\hline June & 6.5 & 9.2 & 7.8 & 3.4 & 6.0 & 3.9 \\
\hline July & 7.5 & 6.6 & 21.5 & 14.5 & 11.7 & 26.9 \\
\hline August & 0.2 & 1.1 & 1.0 & 2.0 & 1.3 & 2.9 \\
\hline September & 5.6 & 2.8 & 5.7 & 3.1 & 9.6 & 3.9 \\
\hline October & 11.9 & 5.6 & 10.7 & 11.8 & 10.3 & 11.5 \\
\hline November & 12.8 & 5.3 & 7.7 & 6.6 & 3.0 & 4.8 \\
\hline December & 20.2 & 11.4 & 17.8 & 2.6 & 2.8 & 2.7 \\
\hline
\end{tabular}

The first two columns report the proportion of wage agreements signed in a given month (i.e. the number of agreements signed in a given month divided by the total number of agreements). The third column reports the frequency of wage change decisions by month, for instance, 9.4 percent of wages are modified by a wage agreement in January. Columns 4 and 5 report the proportion of agreements stipulating a wage change in a given month. The sixth column reports the frequency of effective wage changes by month, for instance, 36.2 percent of wages are modified in January. All these statistics are weighted by the number of workers in each firm. Statistics for agreements are computed over the period 1994-2005 whereas statistics concerning effects are calculated over the period 1994-2001. 
Table 7: Marginal effects $\left(\times 10^{-2}\right)$ of the proportion of days paid the minimum wage on the timing of industry- and firm-level wage agreements (or on their dates of implementation)

Firm-level agreement

Agreement

\begin{tabular}{lcccc}
\hline January & $-0.08^{* *}$ & $-0.22^{* *}$ & -0.13 & $-1.42^{* *}$ \\
February & $-0.11^{* *}$ & 0.00 & -0.05 & 0.02 \\
March & $-0.09^{* *}$ & $-0.14^{* *}$ & 0.11 & -0.01 \\
April & $-0.05^{*}$ & 0.01 & 0.04 & $0.17^{* *}$ \\
May & 0.02 & -0.01 & -0.02 & $0.06^{*}$ \\
June & $0.08^{* *}$ & $-0.06^{*}$ & 0.09 & 0.05 \\
July & $0.06^{* *}$ & $0.17^{* *}$ & 0.09 & $0.28^{* *}$ \\
August & 0.00 & 0.00 & - & 0.00 \\
September & $0.02^{* *}$ & 0.04 & $0.18^{* *}$ & 0.05 \\
October & 0.01 & 0.04 & 0.07 & $0.14^{* *}$ \\
November & -0.01 & 0.01 & -0.12 & 0.02 \\
December & $-0.05^{* *}$ & 0.00 & -0.07 & $0.03^{*}$ \\
\hline
\end{tabular}

Industry-level agreement

Agreement Effect

Each cell of the table reports the marginal effect of the share of days paid at the minimum wage on the probability of signing an agreement or on the probability that an agreement takes effect in a given month. The share of days paid the minimum wage is computed in industries for industry-level agreements, and at a disaggregate level (i.e. at both the industry and local geographical levels for firm-level agreements). The estimated model is a Probit model with random effects, the endogenous variable is a dummy variable being equal to 1 if an agreement is signed in a given month (or if an agreement comes into force in a given month), 0 otherwise. Year dummies, industry dummies, and indicators of the size of the firm are included as control variables in these 12 different estimations.

Symbols: ** means that the marginal effect is significant at the 5 percent level, * means that the marginal effect is significant at the 10 percent level. 
Table 8: Size of wage increases negotiated at the industry-level and at the firm-level (in percent)

\begin{tabular}{|c|c|c|c|c|c|}
\hline & Mean & $\begin{array}{l}\text { Standard } \\
\text { deviation }\end{array}$ & 1st quartile & Median & 3rd quartile \\
\hline \multicolumn{6}{|l|}{ Industry -level } \\
\hline Observed & 3.37 & 2.41 & 2.00 & 2.80 & 4.10 \\
\hline By year of effect & 2.59 & 1.60 & 1.57 & 2.30 & 3.30 \\
\hline \multicolumn{6}{|l|}{ Firm -level } \\
\hline General wage increases & 1.61 & 0.84 & 1.00 & 1.50 & 2.00 \\
\hline \multicolumn{6}{|l|}{ Wage increases } \\
\hline \multicolumn{6}{|l|}{ by occupation: } \\
\hline - blue collar workers & 1.78 & 0.98 & 1.00 & 1.63 & 2.25 \\
\hline - white collar workers & 1.64 & 0.87 & 1.00 & 1.50 & 2.00 \\
\hline - managers & 1.71 & 0.91 & 1.00 & 1.50 & 2.25 \\
\hline
\end{tabular}

Average wage increases at the industry-level are reported in percent and are calculated using the wage grid that has been modified by the new wage agreement. Those average wage increases are extracted from the reports of the Ministry of Labor ("Rapports annuels sur la négociation"), they are available for the period 1999-2006. Average wage increases at the firmlevel are computed for the period 1994-2001 using the wage increase in percentages contained in firm-level agreements. In some agreements, wage increases could be different across occupations. "By year of effect" means that negotiated wage increases are divided by the number of years since the last date of effect of the agreement. 
Figure 1: Duration of wage agreements (in months)

a) Density function

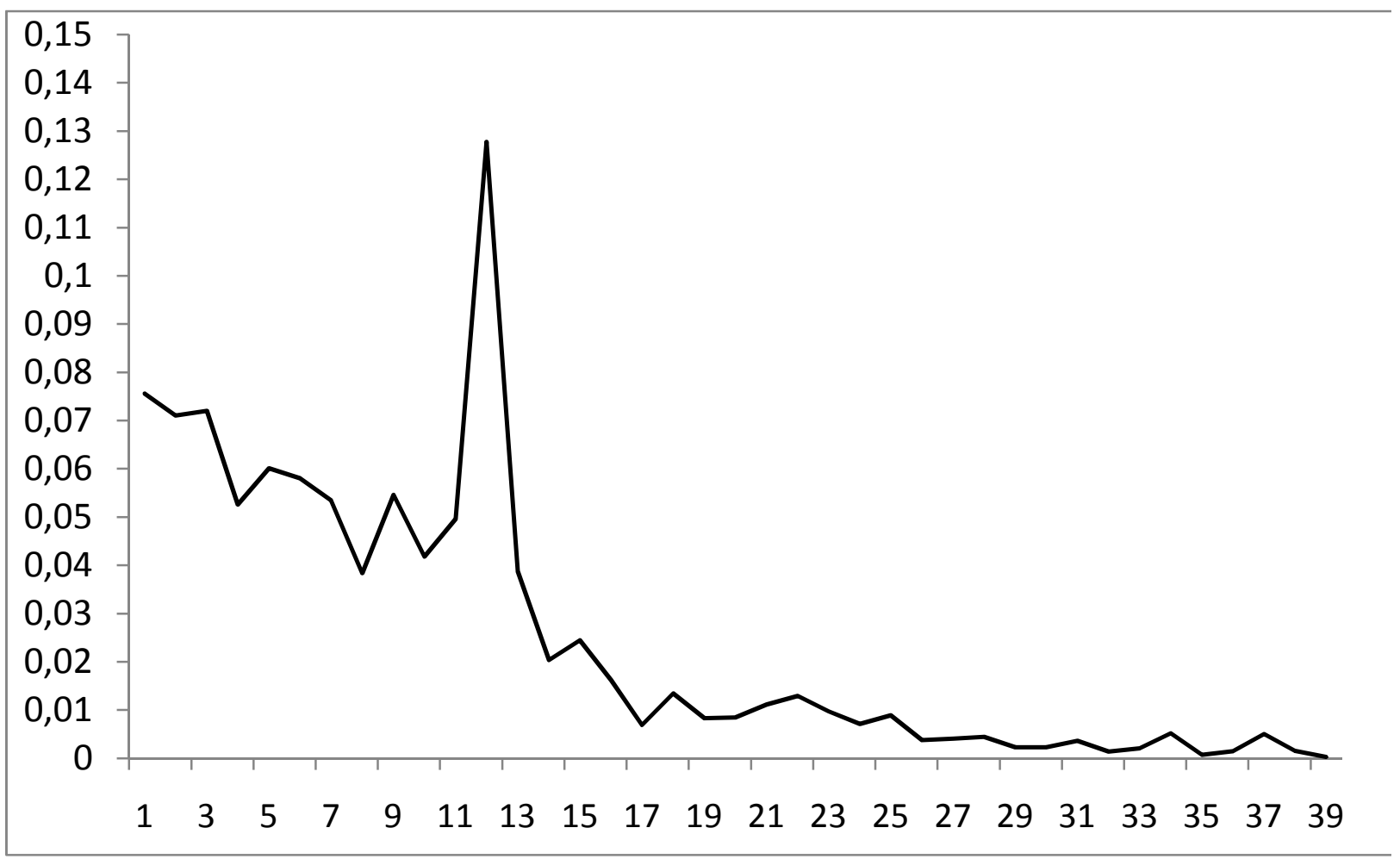

\section{b) Hazard rate}

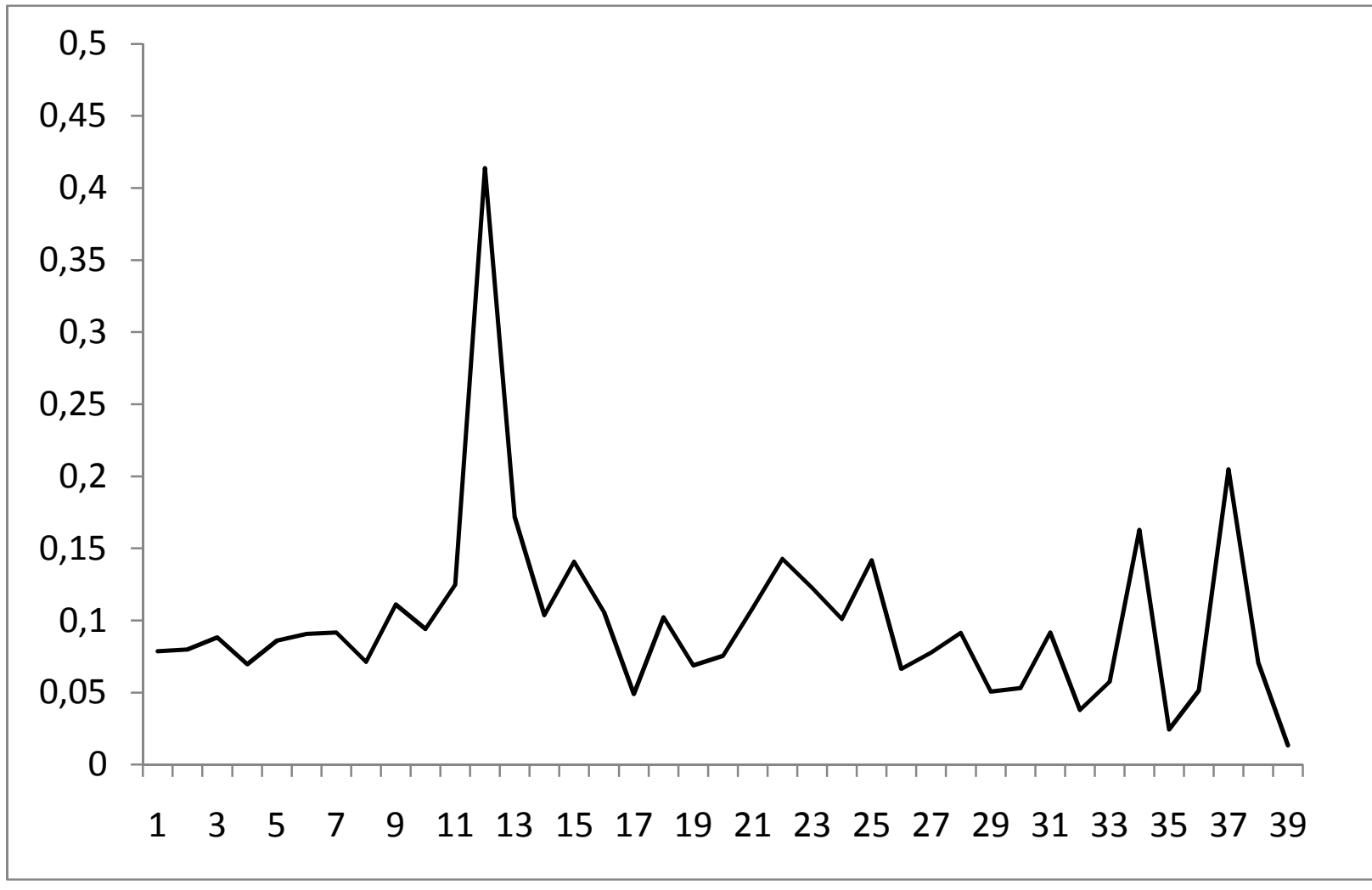

The variable used for calculating durations is equal to one if workers in a given firm are affected by a wage agreement (decision) signed either at the firm- or at the industry-levels, or by a NMW increase. Durations are computed as the difference between two successive agreements (either an industry-or a firm-level agreement or an increase in the NMW). Statistics are weighted by the number of workers in each firm and the number of workers paid close to the NMW. 
Figure 2: Duration between effects of wage agreements (in months)

a) Density function

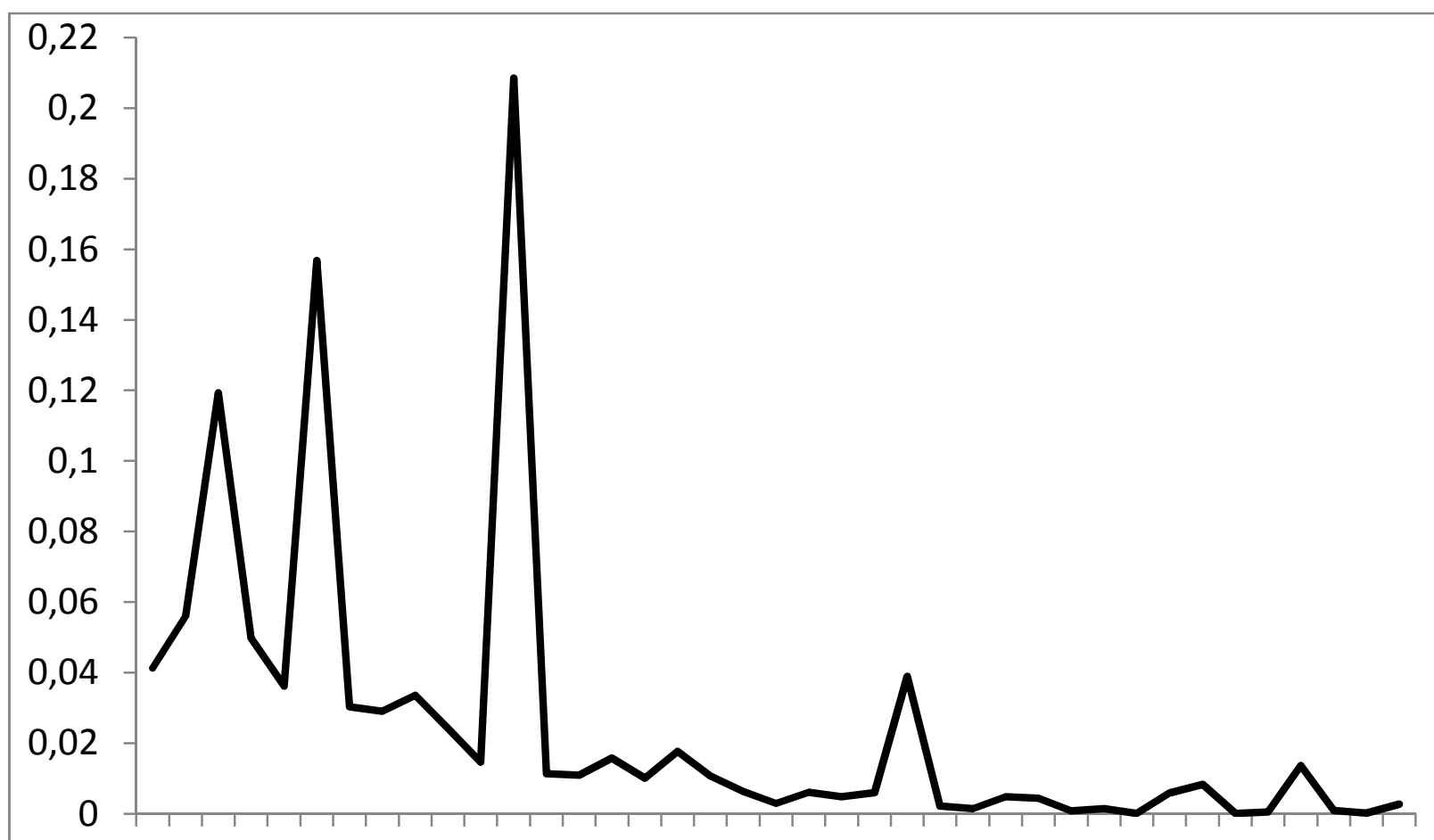

$\begin{array}{llllllllllllllllllll}1 & 3 & 5 & 7 & 9 & 11 & 13 & 15 & 17 & 19 & 21 & 23 & 25 & 27 & 29 & 31 & 33 & 35 & 37 & 39\end{array}$

b) Hazard rate

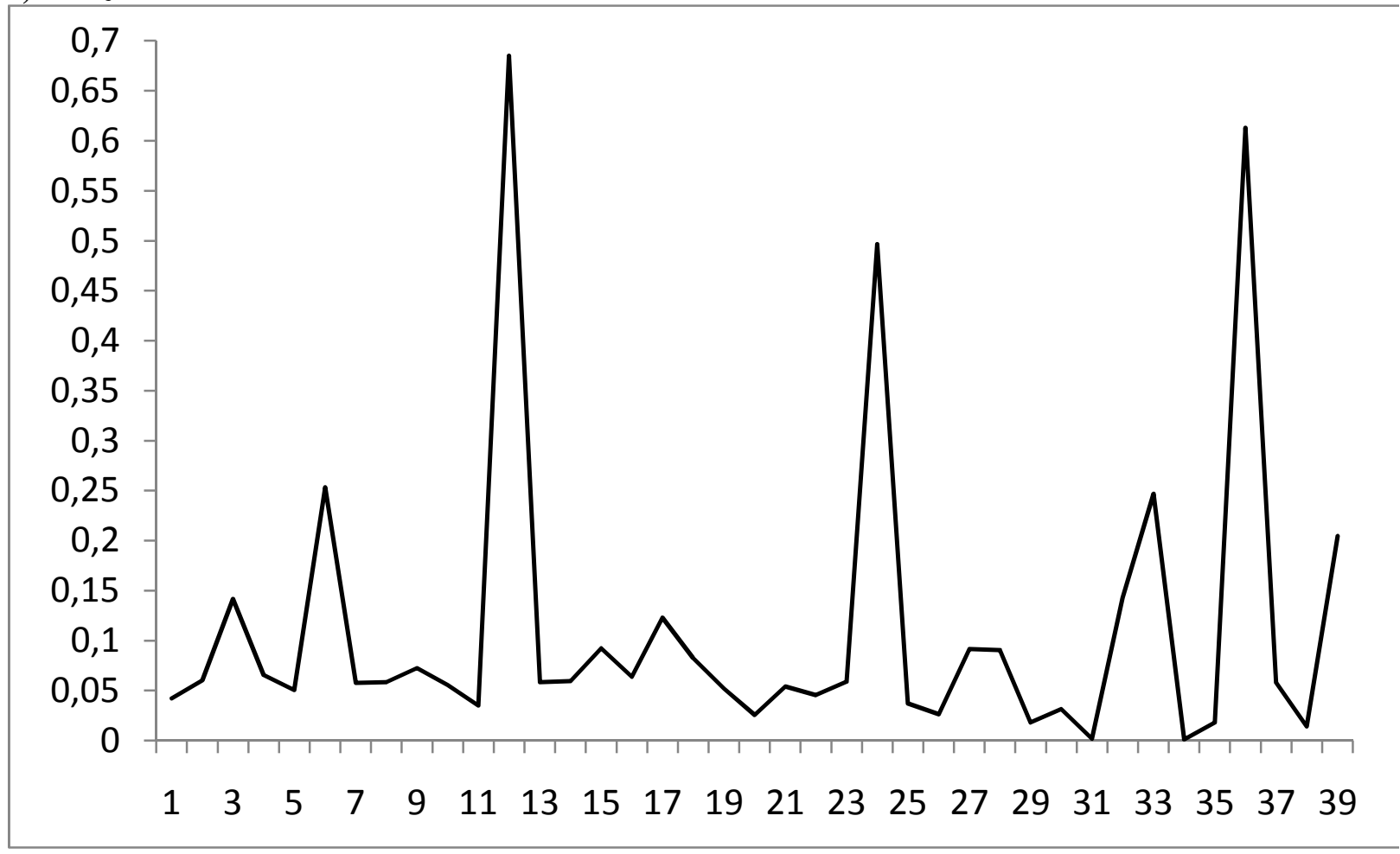

The variable used for calculating durations is equal to one if workers in a given firm are affected by a wage agreement (effect) signed either at the firm- or at the industry-levels, or by a NMW increase. Durations are computed as the difference between two successive effects (either an industry-or a firm-level agreement or an increase in the NMW). Statistics are weighted by the number of workers in each firm and the number of workers paid close to the NMW. 
Figure 3: Number of firm-level and industry-level wage agreements

a) Chemical products industry

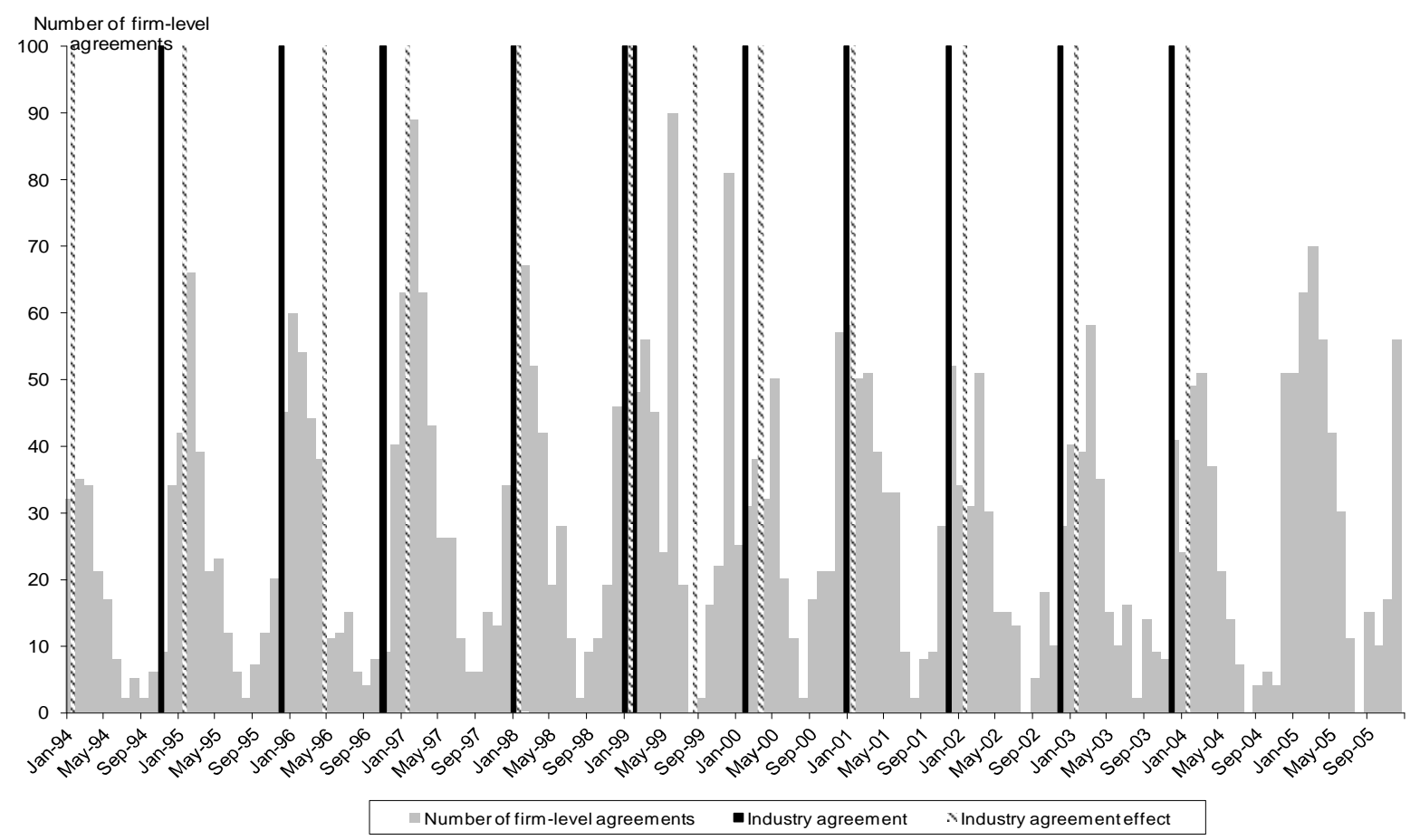

b) Road transportation industry

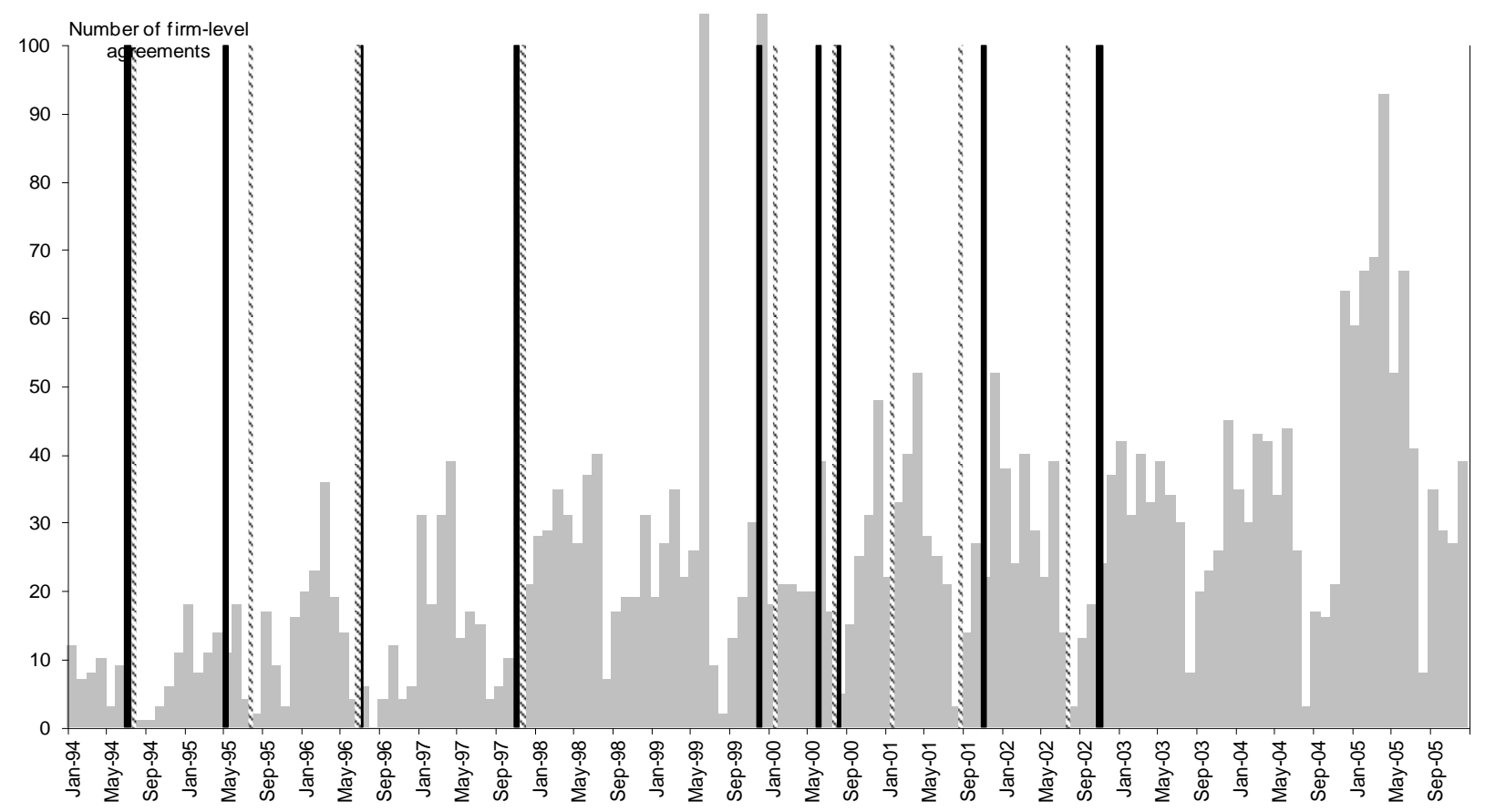

Number of firm-level agreements Industry agreement s Industry agreementeffect

Grey histograms represent the number of firms signing a wage agreement in a given industry each month. Vertical black lines represent the dates of signature of industry-level agreements while vertical doted black lines correspond to the dates of effect of these agreements. 
Figure 4: Wage increases negotiated in industry and firm-levels agreements (in percent)

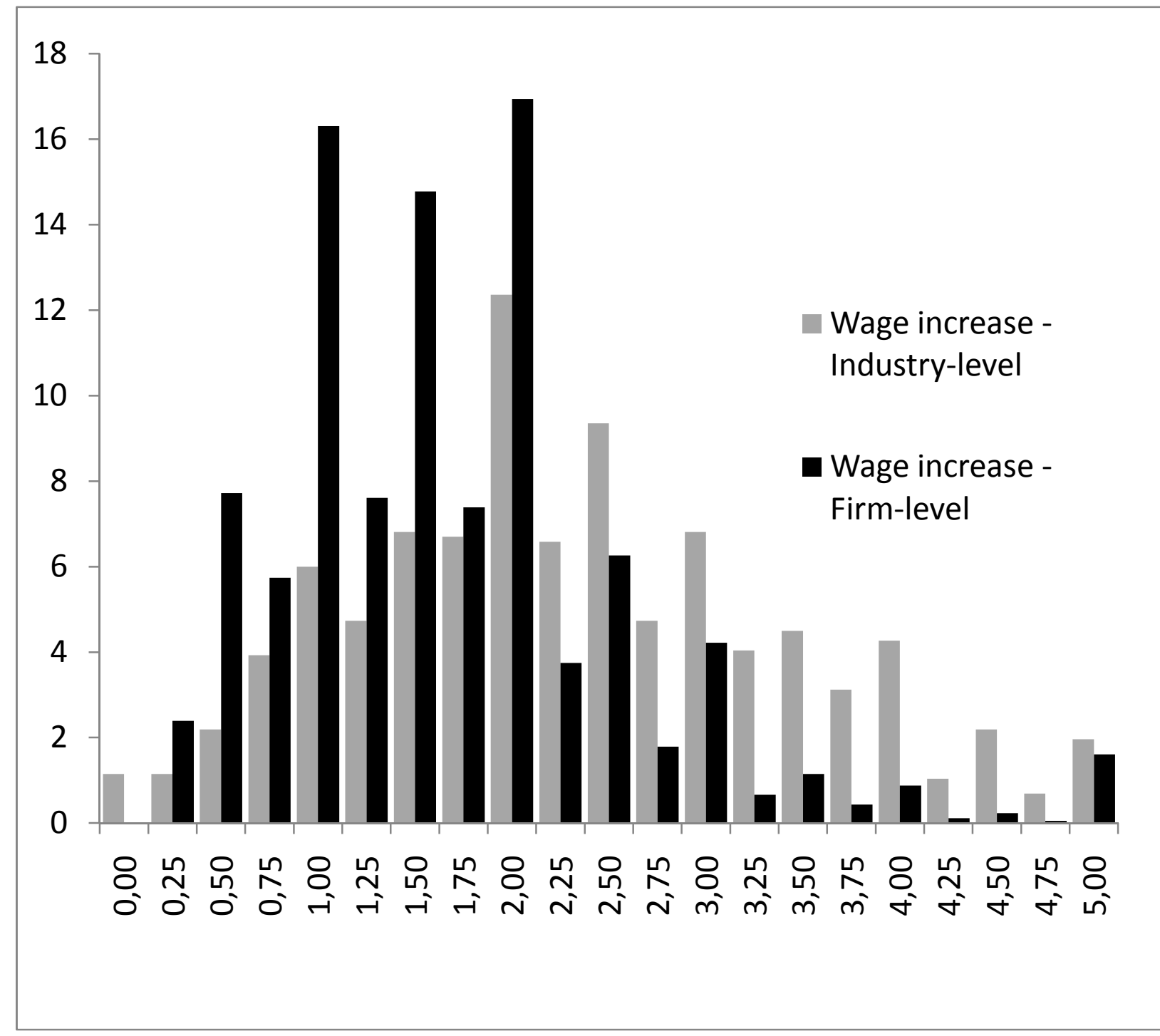

Average wage increases at the industry-level are reported in percent and are calculated using the wage grid that has been modified by the new wage agreement. Those average wage increases are extracted from the reports of the Ministry of Labor ("Rapports annuels sur la négociation"), they are available for the period 1999-2006. Average wage increases at the firm level are computed over the period 1994-2001 using the wage increase (in percentage) which is specified in firm-level agreements. Negotiated wage increases are divided by the number of years since the last date of effect of the agreement. 
Figure 5: Wage increases negotiated in industry- and firm-level agreements over time (in \%)

\section{a) Industry-level agreements}

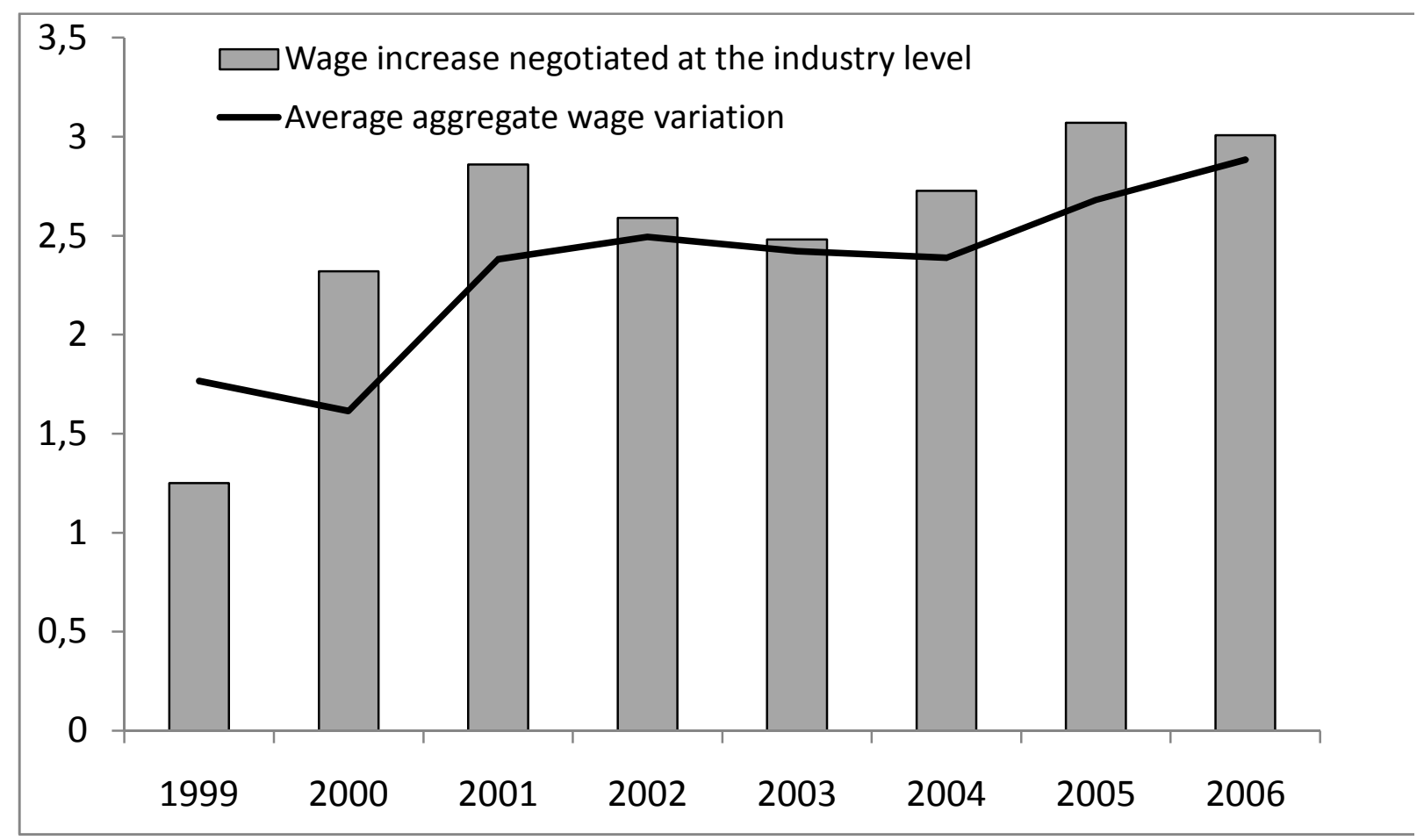

b) Firm-level agreements

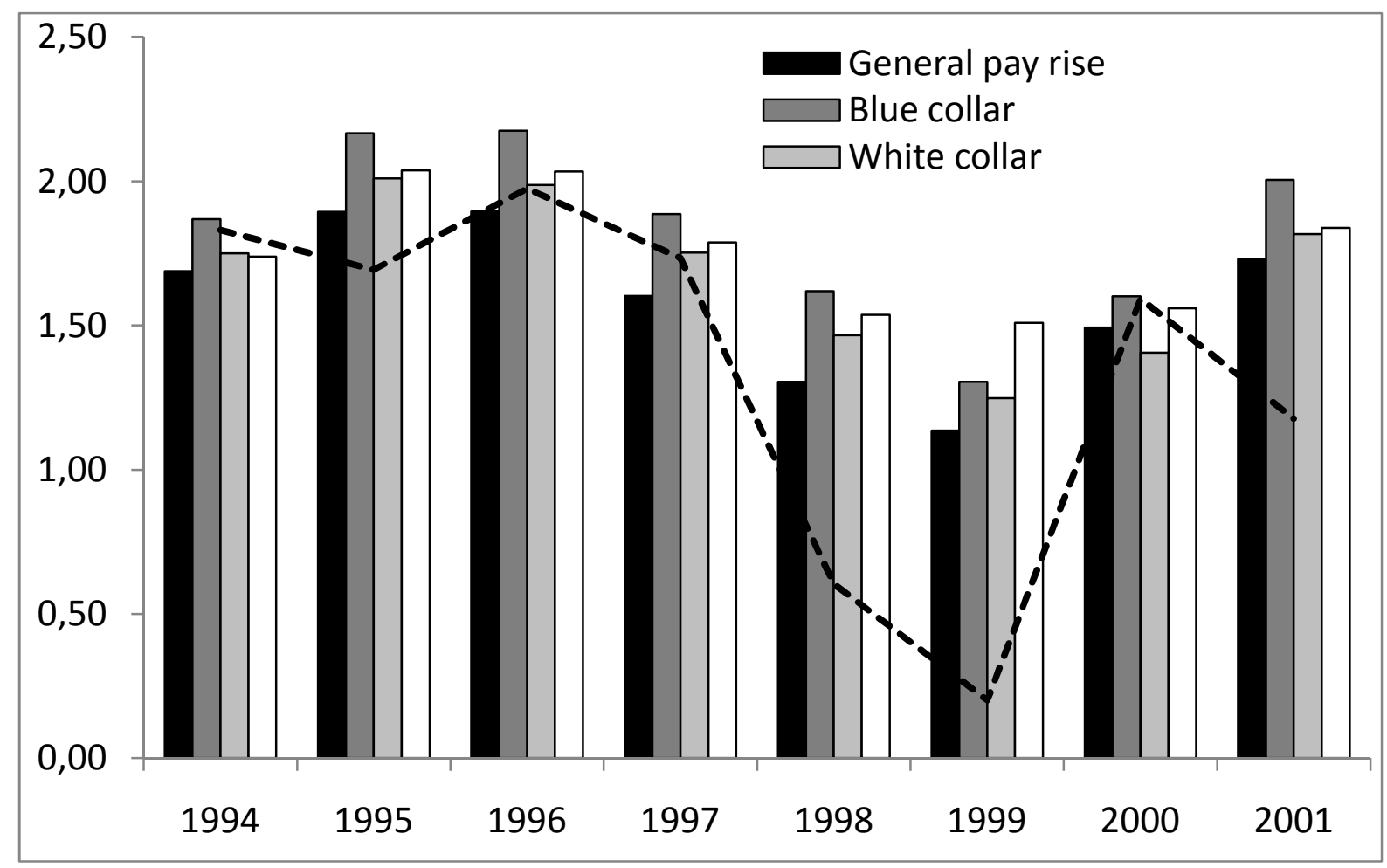

Average wage increases at the industry-level are reported in percent and are calculated using the wage grid that has been modified by the new wage agreement. Those average wage increases are extracted from the reports of the Ministry of Labor ("Rapports annuels sur la négociation"), they are available for the period 1999-2006. Average wage increases at the firmlevel are computed over the period 1994-2001 using the wage increase (in percentage) which is specified in firm-level agreements. In some agreements, wage increases could be different across occupations. Negotiated wage increases are divided by the number of years since the last date of effect of the agreement. 
Appendix

Table A: Proportions of workers covered by an industry-level or by a firm-level wage agreement

\begin{tabular}{|l|c|c|c|c|}
\hline & $\mathbf{1 9 9 4 - 2 0 0 5}$ & $\mathbf{1 9 9 4 - 1 9 9 7}$ & $\mathbf{1 9 9 8 - 2 0 0 1}$ & $\mathbf{2 0 0 2 - 2 0 0 5}$ \\
\hline \multicolumn{2}{|c|}{66.0} & 73.1 & 61.7 & 63.9 \\
\hline Industry-level agreements & 41.4 & 33.6 & 43.3 & 47.1 \\
Firm-level agreements & 21.1 & 19.5 & 22.0 & 21.7 \\
All types of agreements & 27.8 & 22.2 & 30.9 & 29.7 \\
Wage agreements & 51.0 & 58.3 & 47.2 & 48.7 \\
\hline $\begin{array}{l}\text { Industry-level and firm-level agreements } \\
\text { No firm- and no industry-level agreement }\end{array}$ & 6.2 & 4.7 & 7.4 & 6.3 \\
No firm-level agreement but an industry-level \\
agreement
\end{tabular}

The proportion of workers covered by a firm-level or an industry-level wage agreement is computed as the total number of workers in firms covered by an agreement divided by the total number of workers employed in all firms or in a given industry. 
Table B: Summary statistics for the sample (in percent)

\begin{tabular}{|c|c|c|}
\hline & $\%$ of workers & $\%$ of firms \\
\hline \multicolumn{3}{|l|}{ Firm size } \\
\hline Less than 20 workers & 10.5 & 57.6 \\
\hline Between 20 and 50 workers & 16.5 & 26.3 \\
\hline Between 50 and 100 workers & 9.2 & 8.3 \\
\hline Between 100 and 200 workers & 10.5 & 4.4 \\
\hline Between 200 and 500 workers & 13.3 & 2.4 \\
\hline More than 500 workers & 40.1 & 1 \\
\hline \multicolumn{3}{|l|}{ Industry } \\
\hline Agriculture and fishing & 0.3 & 0.6 \\
\hline Food goods & 4.9 & 3.3 \\
\hline Consumption goods & 6.9 & 5.3 \\
\hline Motor vehicles & 3.8 & 0.5 \\
\hline Capital goods & 8.3 & 5.4 \\
\hline Intermediate goods & 15 & 9.4 \\
\hline Energy & 1.3 & 0.2 \\
\hline Construction & 7.8 & 12.7 \\
\hline Wholesale and retail trade & 21.4 & 34.5 \\
\hline Transportation & 7.2 & 6.3 \\
\hline Real estate & 0.8 & 3.2 \\
\hline Business to business services & 18.5 & 13.4 \\
\hline Personal services & 4 & 5.5 \\
\hline \multicolumn{3}{|l|}{ «Branches» } \\
\hline Construction industries & 7.9 & 13 \\
\hline Metal-working industries & 20.6 & 10.6 \\
\hline All industries excluding metal-working and construction & 66.6 & 74.2 \\
\hline Other (no coverage, specific status...) & 4.9 & 2.2 \\
\hline
\end{tabular}

The proportion of workers (resp. firms) by firm size, industry or "branches" is computed as the total number of workers (resp., firms) of a given firm size/industry/"branche" divided by the total number of workers (resp., firms). 